\title{
PRODUCTIVITY GAINS FROM SERVICES LIBERALIZATION IN EUROPE
}

\author{
Jan Bena \\ Peter Ondko \\ Evangelia Vourvachaki
}
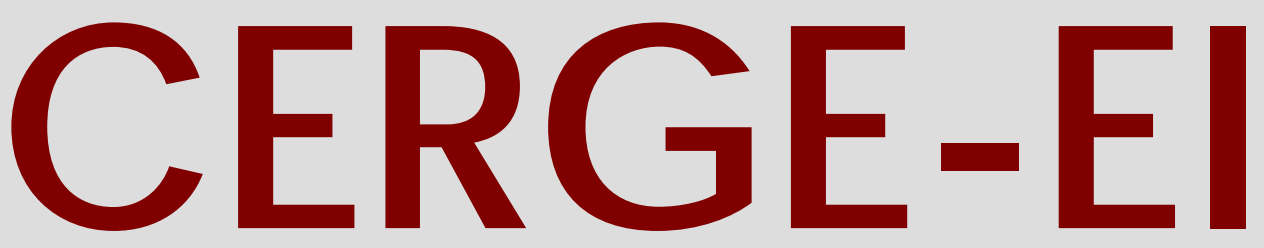

Charles University

CenterforEconomic Research and Graduate Education Academy of Sciences of the Czech Republic Ec onomic s Institute 


\title{
Working Paper Series 452 (ISSN 1211-3298)
}

\section{Productivity Gains from Services Liberalization in Europe}

\author{
Jan Bena \\ Peter Ondko \\ Evangelia Vourvachaki
}

CERGE-EI

Prague, December 2011 
ISBN 978-80-7343-255-3 (Univerzita Karlova. Centrum pro ekonomický výzkum a doktorské studium)

ISBN 978-80-7344-247-7 (Národohospodářský ústav AV ČR, v.v.i.) 


\title{
Productivity Gains from Services Liberalization in Europe ${ }^{1}$
}

\author{
Jan Bena \\ University of British \\ Columbia
}

Peter Ondko

CERGE-EI

\author{
Evangelia \\ Vourvachaki \\ CERGE-EI
}

\section{November 2011}

\begin{abstract}
As part of the Single Market Program the European Commission commanded the liberalization and regulatory harmonization of utilities, transport and telecommunication services. This paper investigates whether and how this process affected the productivity of European network firms. Exploiting the variation in the timing and degree of liberalization efforts across countries and industries, we find that liberalization increased firm-level productivity but had no reallocation impact. Based on our estimates, the average firm-level productivity gain from liberalization amounts to 38 percent of the average total within-firm productivity gain in network industries. The results underscore the growth-promoting role of liberalization efforts.
\end{abstract}

\begin{abstract}
Abstrakt
Jako součást programu jednotního trhu, Evropská Komise nařídila liberalizaci a harmonizaci regulací sektorů utilit, dopravy a telekomunikačních služeb. V tomto článku zkoumáme jestli a jakým způsobem tento proces ovlivnil produktivitu firem v Evropských sít'ových odvětvích. S využitím variace $v$ časování a rozsahu liberalizačních snah mezi krajinami a sektory jsme zjistili, že liberalizace zvýšila firemní produktivitu, ale neměla realokační vliv. Na základě naších odhadů, průměrný růst firemní produktivity způsoben liberalizací činil 38 procent celkového průměrného růstu firemní produktivity $\mathrm{v}$ sít’ových odvětvích. Tyto výsledky zdůrazňují prorůstovou roli liberalizačních snah.
\end{abstract}

JEL codes: D24, K23, L11, L51

Keywords: productivity, liberalization, allocative efficiency, services, firm-level data

\footnotetext{
${ }^{1}$ Financial support from the Economics Education \& Research Consortium (Grant № 10-1491) and the Grant Agency of the Czech Republic (Grant № P403-111-2293) is greatly appreciated. Jan Bena acknowledges the financial support from the Social Sciences and Humanities Research Council of Canada (SSHRC). CERGE-EI is a joint workplace of the Center for Economic Research and Graduate Education, Charles University, and the Economics Institute of the Academy of Sciences of the Czech Republic. The authors would like to thank Christos Genakos, Christian Fons-Rosen, Stepan Jurajda, Steve Rivkin, David G. Tarr, Vladimir Vakhitov, Diana Weinhold, all the panels of experts and participants of EERC workshops, and conference participants at the 2011 Econometric Society European Meeting for useful comments and suggestions. Corresponding authors: Peter Ondko and Evangelia Vourvachaki, CERGE-EI, P.O. Box 882, Politickych veznu 7, 11121, Praha 1, Prague, Czech Republic.

Email: peter.ondko@cerge-ei.cz, evangelia.vourvachaki@ cerge-ei.cz.
} 


\section{Introduction}

In advanced economies, services grow continuously in their importance as final goods and also as inputs in production. ${ }^{2}$ In view of their potential to strongly affect economy-wide performance, the European Commission extended its Single Market Program to services. In this process, the Commission commanded the liberalization and harmonization of services regulation among the EU member countries. The reforms were first implemented in network services industries: telecommunications and post, transportation and utilities. Such a policy priority stemmed from the fact that network services were highly regulated and often monopolized in the EU. As services provided by network industries are essential inputs to other industries, the European Commission envisaged a large scope for gains throughout the economy from increased competition. While a single market for services is currently incomplete and subject to active policy debates, the scope for productivity gains from such regulatory efforts remains largely unknown.

In this paper, we investigate the impact of the European network services liberalization on productivity. Specifically, we ask: What is the impact of liberalization on the productivity of European network services firms? Has liberalization improved the allocation of resources across firms by bringing gains in the production scale of the relatively more productive firms? What is the quantitative importance of these margins? While we address important policy questions we make a relevant contribution to the literature that examines how competition affects aggregate productivity.

The building blocks of our identification strategy are the following: First, unlike for other services, the removal of state monopolies and entry barriers for network industries is mostly complete to date. Second, we rely on measures of liberalization that capture the compliance of member-country regulations with the European Commission liberalization commands. Third, we put forward an empirical framework where we identify the impact of liberalization on within-industry

\footnotetext{
${ }^{2}$ As an illustration, market services in the Eurozone in 1970 accounted for $26 \%$ of intermediate production and $39 \%$ of value added. Their contribution increased to $36 \%$ and $50 \%$, respectively, by 2007. This excludes the community, social and personal services (NACE codes L to Q) that alone account for $20 \%$ of total production.
} 
productivity moments using cross-country variation in the extent and timing of liberalization. ${ }^{3}$ Importantly, we exploit variation due to the EU-wide harmonization principle, while controlling for latent factors that shape policy or productivity outcomes.

To address these questions, we use a European firm-level dataset, which spans the entire liberalization window (1998-2007). The main findings highlight that the liberalization induced an important increase in firm-level Total Factor Productivity (TFP). Namely, the within-firm gains from liberalization are quantitatively important as they amount to $38 \%$ of the actual within-firm productivity gains in our sample. Meanwhile, there is no evidence that the more productive firms grew disproportionately more in size due to liberalization.

Our findings show that institutions that foster competition are important for achieving high productivity outcomes. They are consistent with the view that regulatory distortions, like product market regulations, can distort firm-level decisions concerning investment, employment and technology (adoption or innovation), and thereby negatively affect firm-level and aggregate performance. Moreover, our findings support the view that the presence of "bad" regulations across EU members is an impediment for Europe's competitiveness and future growth (e.g., see the Sapir et al., 2004).

In fact, "bad" product market regulations can have particularly severe productivity implications in the presence of strong growth opportunities, as was the case with the rapid diffusion of the Information and Communication Technologies (ICT) in the 1990s (e.g., see Jorgenson et al., 2005). Indeed, the emergence of the "new economy" triggered a persistent divergence in aggregate productivity between Europe and the United States (van Ark et al., 2008). Multiple studies (e.g., Oulton and Srinivasan, 2005; Inklaar et al., 2005; Inklaar et al., 2008) show that the main driver of Europe's underperformance is the poor productivity growth of the European distribution, financial and business services. Importantly, these industries are fully

\footnotetext{
${ }^{3}$ The observed variation in policy change is driven by the initial level of regulation in each country and the policies taken to meet the European command for harmonization of regulations. See also Section 4.1.
} 
open to competition in the United States, but remain highly segmented and regulated in Europe (see Inklaar et al., 2008 and Arnold et al., 2008 for a review). ${ }^{4}$ In sharp contrast, Europe maintained its competitiveness in manufacturing and network services during the ICT episode (Inklaar et al., 2008). Given that manufacturing was already fully liberalized in Europe by the early 1990s, and in view of our evidence of strong productivity gains from network services liberalization in the 1990s, there is an important scope for productivity gains from extending the EU-wide liberalization program for services. ${ }^{5}$

Our findings are in line with the conclusions coming from earlier studies of the productivity implications of policy-induced liberalizations. In this stream of research, multiple studies concern a single country (e.g., for the case of trade liberalization in Columbia see Eslava et al., 2009), or a single industry (e.g., for telecommunications in the United States see Olley and Pakes, 1996). As such, they are vulnerable to concerns regarding the endogeneity of the liberalization policy or the external validity of the results. Our approach that combines multiple industries and countries reduces these concerns and makes our evidence a valuable contribution.

Our evidence in support of the growth-promoting role of competition is also consistent with the insights from studies that look into the impact of competition on productivity without exploiting specific regulatory reforms. This is the case in Bloom et al. (2011) who investigate the role of import competition from China for European firms. For a broader sample of countries, Bartelsman et al. (2009) relate the crosscountry productivity differences with market distortions that result in misallocations of resources across firms.

Finally, it is worth noting that our empirical specification is very different from the one based on neo-Schumpeterian models that features in earlier studies of

\footnotetext{
${ }^{4}$ In the United States, professional services industries took advantage of the growth opportunities associated with ICT. Specifically, United States services exhibited strong labor productivity due to both strong capital deepening, particularly of ICT, and strong TFP growth (e.g., see Bosworth and Tripplett, 2002, Basu et al., 2003).

${ }^{5}$ That more competitive services can foster aggregate economic performance is further supported by Barone and Cingano (2011), who show for a sample of OECD countries that manufacturing industries that use services inputs grow faster more intensively in countries with lower services regulatory burdens.
} 
the within-industry productivity impact of services liberalization in Europe. In this line of research, Nicoletti and Scarpetta (2003) use industry-level data to investigate the neo-Schumpeterian prediction that industries closer to their technological frontier grow faster in more liberalized markets. They find no support that the level of competition in services has a positive impact on their own productivity growth. In contrast, Inklaar et al. (2008) find evidence of such a positive effect, when they restrict their sample to network services. ${ }^{6}$ This underscores the limitations in Nicoletti and Scarpetta (2003) that captures services liberalization using an Input-Output weighted average of measures of restrictive regulations for all services, independently of whether they are liberalized or not. ${ }^{7}$ Their approach introduces a downward bias in their estimate of the impact of liberalization. In addition, their measure of liberalization is hard to interpret, as its variation does not come from removing regulatory barriers within each specific services industry and is confounded with the regulatory barriers of other industries. ${ }^{8}$ To overcome such limitations, we focus on the productivity impact of industry-level regulatory barriers. We also highlight that the existence of within-industry differences in liberalization across countries provides the necessary variation that allows the identification of different sources of productivity gains.

This paper is organized as follows. Section 2 summarizes the related theoretical and empirical literature, Section 3 presents our data, Section 4 lays out our methodology, Section 5 presents our results and Section 6 concerns our robustness checks. Finally, Section 7 concludes.

\section{Theoretical Considerations and Hypothesis Development}

The removal of industry distortions, like regulatory entry costs or the abolition of state monopolies, is expected to increase competition among firms. Models of industry equilibrium with firm heterogeneity highlight that such a liberalization policy would

\footnotetext{
${ }^{6}$ See also Boylaud and Nicoletti (2001) for telecommunications alone.

${ }^{7}$ A similar argument is discussed in Inklaar et al. (2008).

${ }^{8}$ Similar arguments apply to Arnold et al. (2008), who estimate the within-firm productivity gains from liberalization.
} 
affect industry productivity through three distinct channels: first, the within-firm productivity growth for the continuing firms in the industry that corresponds to the intensive margin of aggregate productivity; second, the within-industry productivity growth across firms' reallocation of resources, e.g., labor and output shares and third, the selection mechanism, meaning the entry and exit decisions of firms. The latter two channels correspond to the extensive margin of aggregate productivity growth. Even though theory is clear about the margins of competition impact on aggregate productivity, it bears mostly confounded predictions regarding their direction.

In particular, there are ambiguous theoretical predictions regarding the ultimate direction of the within-firm growth channel. This is because higher competition can affect firm-growth in a number of ways that can go in opposite directions. First, continuing firms decide to expand their production capacity via physical investment. Alesina et al. (2005) show that high competition results in lower profit margins and thus lower shadow price of capital, which increases firm investment rate. However, this result is challenged in the presence of formerly government backed monopolies that tend to have inefficiently large production capacity. ${ }^{9}$

Second, competition impacts the TFP of incumbents because it affects incentives to adopt new technologies or innovate. Acemoglu et al., (2006) show that for firms that are away from their industry's technological frontier it is optimal not to innovate, but instead adopt the best-practice technologies. For such technologically laggard firms, competition creates stronger incentives to invest in the adoption of the frontier technologies (see Parente and Prescott, 1994). To the contrary, for firms that are close to their industry technology frontier competition bears a non-linear effect on their innovation decisions and thereby growth (Aghion and Howitt, 1998; Aghion et al., 2005).

In particular, the neo-Schumpeterian models highlight that innovation incentives are driven by the difference between pre-innovation and post-innovation rents. If competition reduces pre-innovation rents, it increases the incremental payoff

\footnotetext{
${ }^{9}$ Similarly, theory does not provide clear guidance regarding what to expect from the impact of competition on the capital intensity (capital-labor ratios) of firms.
} 
from innovation and encourages innovation as a means of "escaping competition". In contrast, if competition reduces post-innovation rents, it discourages innovation through the standard "Schumpeterian effect". These imply an inverse-U relationship between competition and innovation activity within an industry, i.e., increased competition would have a positive impact on industry innovation only for low levels of initial competition. The results further highlight that the peak of the inverse-U relationship will occur at a higher degree of competition level in more "neck-andneck" industries, i.e., where firms already compete closely. Therefore, removing entry barriers in industries with very low or no competition is expected to cause higher innovation and thereby growth. The effect should be higher the more increased competition reduces pre-innovation rents.

An additional explanation why competition can foster within-firm productivity is provided by the "trapped factors" hypothesis of Bloom, Van Reenen and Romer (2010). The "trapped factors" refer to inputs, like human capital skills, that are highly firm-specific. When a firm faces higher competition in producing low-tech products, then the opportunity cost of its trapped factors falls. As a result, when the incumbent firms can innovate more easily than its competitors, then it has an incentive to reallocate its factors towards innovation and the production of high-tech goods.

Finally, firms can grow due to an improvement in their managerial quality. ${ }^{10}$ The impact of competition on managerial incentives is ambiguous in environments featuring asymmetric information/moral hazard problems (see Nickell, 1996, for a review). On the one hand, competition can increase managerial effort and reduce slackness, either by increasing the threat of firm liquidation or by an improvement in the quality of the manager's monitoring. The latter is due to the fact that competitors' performances offer owners additional sources of information for aggregate productivity shocks. On the other hand, managerial incentives worsen if managerial compensation packages are aligned to firm profits that are eroded by competition (see Vickers, 1995). Schmidt (1997) consolidates these opposing effects of competition to show that starting from the state of monopoly, there is a U-shaped effect of higher competition on managerial slackness. If managerial slackness results in lower

\footnotetext{
${ }^{10}$ See Bloom and Van Reenen (2007) regarding the importance of managerial practices for firm-level productivity.
} 
productivity, this suggests a nonlinear effect of liberalization on firms with initially different levels of productivity.

A heterogeneous effect of liberalization across firms could be also driven by regulations that are explicitly tied to firm size or by aggregate regulations that can have asymmetric effects across firms in the presence of additional market frictions, like those relating to capital or labor inputs (e.g., see Guner et al., 2008). For example Beck et al. (2005) provide evidence that industries with a higher share of very small firms in the United States grow faster in countries with more developed financial systems, suggesting that small firms face higher constraints in obtaining external financing.

Turning to the remaining margins of industry productivity, it is worth noting that in a frictionless environment, in the spirit of Lucas (1978), firm size should be perfectly correlated to firm productivity. Thus, any deviations from the optimal allocation of resources across productive units due to regulatory costs would distort aggregate productivity downwards. ${ }^{11}$ Indeed, a reduction of entry costs in static models of industry equilibrium with heterogeneous firms implies a positive withinindustry reallocation of resources across firms (see Melitz, 2003; Melitz and Ottaviano, 2008). This is because as a response to the lower entry costs there is increased firm entry, so that a higher number of firms compete in the market. This results in lower average markups and profits, so that the productivity cut-off for surviving in the industry increases in the long-run. In other words, increased competition induces the least productive firms to exit and shifts resources towards the most efficient firms in the market. As a result, industry productivity increases.

While the selection margin is clearly predicted to contribute positively to industry productivity in the long run, this is not necessarily the case in the short run. The transition dynamics of the Melitz (2003) model suggest that in the short run the productivity of the entering firms is lower than before the removal of entry barriers, as

\footnotetext{
${ }^{11}$ There is a large and growing literature that attributes low aggregate productivity to differences to the misallocation of resources within/across firms (see Banerjee and Duflo, 2005). This line of research highlights the role of aggregate or firm-specific policy-driven distortions in creating the scope for such misallocations, particularly in environments with firm-heterogeneity in productivity (e.g., Hsieh and Klenow, 2009, Bartelsman et al., 2009, Guner et al., 2008, Restuccia and Rogerson, 2008).
} 
the firms that enter are the initially "marginal" ones that were previously deterred (a similar argument is featured in Branstetter et al., 2010). At the same time, there are dynamic models of industry equilibrium, like vintage capital or neo-Schumpeterian models where it is shown that entrants have the strongest incentives to be on the technological frontier. All this discussion suggests that the role of selection is open to empirical investigation.

To summarize the empirically testable predictions derived from the theory: Competition can affect within-firm productivity outcomes, but the predicted direction of its effect is not clear. Moreover, higher competition is predicted to induce the more productive firms to grow in size and enjoy higher market shares. The number of entrants and number of firms in an industry is expected to go up while there are ambiguous predictions about their productivity identity compared to the average firm in the liberalized industry.

We are able to investigate the direction of within-firm productivity impact of liberalization and test the hypothesis of the positive reallocation of resources. Due to our data limitations that are illustrated in the following section, we are not able to investigate selection through exit and entry at a reasonable level of precision.

\section{Data and Sample}

\subsection{The OECD measure of product market regulation in network services: The "ETCR"}

Starting from 2001, the OECD produces indicators of product market regulation-the "ETCR" indexes-for the network services: telecommunications and post, railways, road freight, airlines, electricity and gas. The industry-level indicators are broadly available for 21 OECD countries and cover the period 1975-2007. Details about the construction of these indexes are in Conway and Nicoletti (2006). ${ }^{12}$

\footnotetext{
12 For detailed documentation and recent data updates see the OECD webpage: http://www.oecd.org/document/36/0,3343,en_2649_34323_35790244_1_1_1_1,00.html.
} 
The ETCR index for each industry is a quantitative measure that ranges between 0 and 6 , "reflecting increasing restrictiveness of regulatory provisions to competition". The construction of the industry-level ETCR indexes is based on two principles. First, the regulations in each industry-country are judged in terms of their restrictiveness only in areas where the regulation theory and technological features suggest that there is scope for market competition. Therefore, an industry ETCR index does not judge regulatory outcomes in cases of "natural monopolies", i.e., large economies of scale. This principle is particularly important for the network services that are the subject of our study. Second, the industry-level ETCR indices are constructed on the basis of qualitative information in the Regulatory Indicators Questionnaire provided by national governments (1998, 2003 and 2008) and complemented by OECD and other international organizations data. Hence, these indicators are in spirit fully "objective measures" of competition that aim to capture the stance of the regulatory environment in a given country-industry with respect to promoting market competition. This makes the measures of restrictive regulations we use robust to any bias related to local market conditions and the stage of the business cycle. $^{13}$

Finally, the ETCR indexes cover a number of regulatory areas summarized using more disaggregated indexes of product market regulation. The regulatory areas for network services are barriers to entry, public ownership, price controls, market structure and vertical integration. The industry-specific indicators differ in terms of which of these regulatory areas are covered, and they are summarized in Table A1 of the Appendix. This cross-industry variation reflects the relevance of each regulatory area for a particular industry. In this regard, it is worth noting that regulatory barriers to entry and public ownership are the two areas that are universally covered. The areas of market structure and vertical integration are meant to capture the enforcement or effectiveness of the regulations as they reflect the dimensions of the actual industry competition stance.

\footnotetext{
${ }^{13}$ Such a bias is a concern in the case of "subjective" competition measures that are based on individual responses to surveys. For a detailed discussion of the relevant advantages of the "objective" measures see Nicoletti and Pryor (2006).
} 
We summarize the information on product market liberalization for each industry-country at two levels. First, we use the "Index of Overall Liberalization" (IOL) that includes information on barriers to entry and public ownership only. We leave out the lower-level indexes that capture market structure and vertical integration, because they are prone to be contaminated by factors that are endogenous to drivers of industry-performance. Second, we employ the "Index of Entry Liberalization" (IEL) that concerns exclusively entry regulation. We examine in isolation the role of entry regulations because they refer solely to the de jure elements of the regulatory environment. In contrast, the information in IOL regarding state ownership share is indicative of incumbent market power and effective barriers to entry, and as such it captures also de facto elements of the competition environment. To ease the interpretation of the results of our empirical investigation, we measure both indices on scale of 0 to 6 , where 6 corresponds to the most liberalized marked and 0 to the most regulated market.

To facilitate the intuition for how a unit-change in IOL maps onto changes in the regulatory environment of the industry, consider the following hypothetical scenario for the case of telecommunications. Assume that the industry started with the highest degree of regulatory barriers and presence of monopoly: IOL score 0 . A one-unit improvement for such a telecommunications industry would require that "legal conditions of entry into the trunk, international and mobile telephony" changed from "franchised to 1 firm" to "franchised to 2 or more firms". A full removal of entry barriers, i.e., a change in such legal conditions to "free entry" would cause a six-unit change in IEL but a three-unit change in IOL. Thus, IOL can increase by more than three units only if the removal of entry barriers are accompanied by a reduction in the percentage of public ownership "of shares of the largest firm in the mobile telecommunications sector" and in "public telecommunication operator" by at least $50 \%$ of their initial level on average. ${ }^{14}$

\footnotetext{
${ }^{14}$ The average four-year change in IOL amounts to 0.66 points in our sample. The IOL is an equalweights' average of public ownership and entry sub-indices, for which the average four-year change is 0.95 and 0.39 , respectively. Thus, more than two-thirds of the observed change in IOL is driven by the change in the entry sub-index.
} 


\subsection{Firm-level data}

In order to track the contributions of individual producers to the dynamics of the productivity of an industry, we use Amadeus, a European-wide, firm-level dataset. It is compiled by Bureau Van Dijk (BvD) by harmonizing companies' annual reports obtained from various European vendors. The key advantage of Amadeus for our purpose is that it covers both public and private companies of all size categories across all industries for most countries.

Amadeus is available in multiple updates that add information over time. Every update contains a snapshot of the currently active population of firms as well as up to the 10 most recent years of firms' financial data (if available). Also, a given firm is present in Amadeus as long as it provides its financial statements; however, it is kept in the database only for four years after its last filing. For example, a firm that files financial statement in 2002 but stops filing in 2003, remains in the database until 2006. In 2007 the firm is dropped from the sample and all year entries of the firm are taken out of the Amadeus database. Given this feature of Amadeus, we construct our dataset by combining several updates, specifically DVD updates from May 2002 and May 2004 together with updates downloaded from WRDS in July 2007, April 2008, August 2009 and February 2010. This procedure allows us to add back observations for firms that are not present in more recent updates. The key advantages of this procedure are that first, it eliminates the survivor bias inherent in a single-update data and second, it extends firms' historical accounting data beyond the most recent 10 years.

We use also the EU KLEMS database in order to obtain country-sector specific output and intermediate inputs deflators with the base year being 1995. EU KLEMS uses the two/three digit NACE rev. 1.1., which is broader than the classification of industries in this study. For this reason, we need to use the same aggregate deflator for all industries within a given EU KLEMS two/three digit sector. The correspondence between the EU KLEMS sectors and the network industries for which OECD reports ETCR indexes is summarized in Table A2 of the Appendix. 


\subsection{Final sample}

To construct our final sample from Amadeus, we first select all firm-year observations in the industries of interest for which the values of revenues, fixed assets, material costs and employment variables are not missing. When the total wage bill is available, but employment is missing, we impute employment as the ratio of the total wage bill over the average wage of the corresponding industry. The latter is estimated as the simple average of wages calculated over firms in the same industryyear that report both the total wage bill and employment. Next, we drop all observations of firms with less than 20 employees, since their reported information is often missing or likely unreliable. Then, we drop observations in the top percentile of employment and revenues distribution as it is likely that these correspond to conglomerates operating over many markets that could bias our results. Last, we drop the Netherlands, Luxemburg and Slovakia, countries for which there are too few observations.

Table 1 reports the descriptive statistics for value added per employee, employment and IOL for our final unbalanced sample that spans 6 network services industries over the period 1998-2007. There is substantial cross-sectional variation in labor productivity and employment for the median firm in our sample. Labor productivity is the highest for the median firms in France, Germany and Austria, with Sweden following closely. At the bottom end of labor productivity feature the former transition countries (the Czech Republic, Hungary and Poland). Countries differ also in terms of the level of restrictive regulations in their network industries in 1998: France and Italy, together with the group of former transition countries, are among those with the most restrictive regulations in 1998. By 2007, however, the regulatory environments of EU countries had converged. Indeed, Table 2 shows that countries that started as the most restrictive are the ones that experienced stronger liberalization over the sample period. The group of highly liberalized industries involves telecommunications, gas and electricity services. On the contrary, post and railways are among the least deregulated industries.

Table 3 reports the descriptive statistics across industries in our sample. Airlines, electricity and gas services have the highest median labor productivity, presumably because of the high capital intensity of these industries. Median firm size appears to 
be more balanced across industries, and it is the highest in the transportation industries, airlines and railways. The electricity industry is the one most represented in our sample.

\section{Methodology}

\subsection{Identification strategy: The European Union legal framework for services liberalization}

The crucial assumption for the identification of the effect of liberalization on productivity is that the EU-wide regulations aimed at liberalization are not driven by local market and growth conditions. This is ensured by the EU legal structure. In particular, all liberalization policies that are part of the EU's Single Market Program are based on a series of Directives that are approved by majority voting in the European Parliament. Directives set out the objectives and timeframe of reforms. Such reforms are based on the need to ensure European-level outcomes and are thus independent of country-specific circumstances. In response to the EU Directives, member countries design their own policies to fulfill the reform goals by the set deadline.

Services Directives concern reforms to liberalize and harmonize regulatory frameworks for services among European Union members. They timely followed the liberalization of manufacturing industries in the 1990s, and were largely viewed as a further step towards the fulfillment of the goals of the 1993 Single Market Program for goods. ${ }^{15}$ Services liberalization is consistent with the European Common Market key goal to establish "a single market for goods and services by removal of physical and regulatory barriers". The ultimate goal is to ensure competitiveness and sound long-run growth prospects for Europe. In this process, the European Commission prioritized the liberalization of network services, because of their key importance as inputs for manufacturing. An additional driver for the case of telecommunications was the strong growth opportunities envisaged in relation to ICT. It is worth highlighting

\footnotetext{
15 This is because of evidence that performance in manufacturing can be constrained by services performance (see Ten Raa and Wolff, 2001).
} 
that the removal of entry barriers for services is particularly important for ensuring competition in such markets. This is because they are largely non-tradable and, as such, there is a limited scope for increased competition via imports.

Therefore, in view of the features of EU-wide regulations outlined above, we can argue that industry-specific liberalization reforms during the liberalization windows of the Directives are not initiated based on industry-country specific conditions and productivity prospects. The increasing compliance of countries to the EU Directives for network services liberalization is summarized in Figure 1.a. In our data, there is both a positive trend of IOL across EU member countries as well as indications of shrinking cross-sectional variance. The developments of the median IOL reflect market developments in the electricity industry, which is the median industry in our sample. There, the first and second EU Electricity Market Directives were issued in 1996 and 2003 respectively, with a transposition deadline in 2007. A detailed exposition by industry and country is offered by Figure 1.b (complemented by Table 2).

Our approach is potentially vulnerable to skepticism regarding whether differences in the degree and timing of compliance across countries/industries are driven themselves by local market or growth conditions. For instance, related to the implementation of Electricity Directives, Jamasb and Pollitt (2005) explain the poor performance of Spain and Italy, arguing that regulators appeared "weak in the face of established incumbent company interests" (see also benchmarking reports by the EU). We address such concerns in Section 5.2 appealing explicitly to the harmonization principle.

\subsection{Measures of productivity}

To investigate the impact of liberalization on productivity we estimate firm-level Revenue Total Factor Productivity (TFPR) that captures the efficiency of a firm in generating sales using its inputs and the industry-specific technology. We recover three measures of TFPR: the logarithm of revenue total factor productivity estimated by ordinary least squares (TFPR OLS), the logarithm of revenue total factor productivity estimated by Levinson and Petrin (TFPR LP) and the WooldridgeLevinsohn-Petrin (TFPR W-LP) estimator. 
To estimate all measures of TFPR, we use deflated sales as a measure of output, material inputs measured as material costs deflated by the intermediate inputs deflator, capital approximated by the book value of fixed assets, and labor measured by the number of employees in a firm. Assuming an industry-specific logarithmic Cobb-Douglas production function in capital, labor and materials, TFPR is calculated as the residual of the estimated industry production function.

There are potential sources of bias when estimating a production function. The unobserved productivity shocks known to a firm are likely to contemporaneously affect its input choice, which introduces a "simultaneity bias" to the estimated parameters of the industry-specific production function. ${ }^{16}$ This suggests that when the production function parameters are estimated using OLS, the estimates are subject to a positive bias. This is particularly the case for the estimated parameters on flexible inputs, such as materials. To deal with the simultaneity bias, a number of alternative estimators have been proposed in the literature (see Eberhardt and Helmers, 2010 for a recent review). The most popular estimators are those by Olley and Pakes (1996) and Levinsohn and Petrin (2003). The Olley and Pakes (1996) estimator is based on a set of structural assumptions about the timing of a firm's input choices and their law of motion over time, as well as on the assumption about the firm's productivity process. Specifically, this approach assumes that capital takes (a one-period) "time-tobuild" and that productivity follows a first-order Markov process. In this setting, investment is strictly monotonic in the firm's capital and productivity. Inverting this relationship allows controlling for the unobserved productivity shock using a general function of the observed capital and investment of the firm. As such, this estimation method requires data on capital expenditures, which are not reported in Amadeus. The Levinsohn and Petrin (2003) estimator is based on similar structural assumptions, but is less demanding on data information. Productivity shocks are controlled for using a function of capital and intermediate inputs, which are available in our firm-level data. Using intermediate inputs to proxy for unobserved productivity shocks avoids the

\footnotetext{
${ }^{16}$ Additionally, using a balanced panel can introduce selection bias, if there is no allowance for entry and exit. As discussed earlier, our sample does not suffer from such a bias by construction.
} 
imputation of capital expenditures series from the stock of capital. ${ }^{17}$ Thus, as the second measure of TFPR, we use the one estimated using the Levinsohn and Petrin (2003) approach and we label it 'TFPR LP'.

To the extent that there is collinearity between labor and the non-parametric function of capital and materials that proxy for the unobserved productivity shock, the Levinson and Petrin (2003) estimator may fail to identify the production function parameters of the variable inputs. ${ }^{18}$ For this reason, we also estimate firm productivity using the one-step GMM formulation of the Levinsohn and Petrin (2003) estimator proposed by Wooldridge (2009) that is robust to this potential bias. In addition, the GMM framework provides efficiency gains and allows recovering robust standard errors. In our application, we use a formulation in which unobserved productivity shocks are approximated by a $3^{\text {rd }}$-order polynomial in material spending and capital. Following De Loecker (2011), we estimate an industry-specific, value-added production function in order to ensure the identification of the perfectly variable material input. The double-deflated value added is calculated as deflated revenues minus deflated materials, obtained using the appropriate industry deflators. The resulting productivity measure is labeled 'TFPR W-LP'.

As a final note, since Amadeus lacks firm-level information about prices, our estimates of production function parameters are potentially subject to an "omitted prices bias". If there is a correlation between inputs and firm-level price deviation from the industry-level price index, Klette and Griliches (1996) show that the omitted prices translate into a negative bias of the estimated scale elasticity. This suggests that any TFPR measure would deviate from physical productivity due to price dispersion and the bias in the scale elasticity. This implies that, when we are interested in estimating the impact of liberalization on firm-level productivity, the estimates confound the impact of liberalization on the actual firm-level physical productivity with its impact on the dispersion of prices across firms and demand conditions.

\footnotetext{
${ }^{17}$ Moreover, compared to Olley and Pakes (1996), using the Levinsohn and Petrin (2003) method is a way to avoid dropping observations with zero investment and thus utilize the full sample.

${ }^{18}$ The collinearity is due to the fact that, as an optimally chosen input, labor is likely to also be a deterministic function of the unobserved productivity and capital (see Ackerberg et al., 2006, for a detailed discussion).
} 
De Loecker's (2011) proposed solution for this bias is the structural estimation of the production function, while conditioning for shifts in the CES-based firm residual demand. His identification of the demand parameters relies on the differences in variation in aggregate-level (segment/industry) output and firm-level (product) demand shifts stemming from policy change, in his case tariff liberalization. To disentangle the effect of policy change on productivity from that on demand conditions, he further assumes that a policy change shifts the firm-level residual demand instantaneously and it affects firm-level productivity only with a lag. His strategy is not applicable in our setting since our liberalization index (IOL or EOL) does not vary at the firm level, but only at the country/industry level.

In this context, it is worth noting that, if European network services liberalization was successful in increasing competition, then average prices (markups) and their dispersion would fall over time. This in turn suggests that our estimates would tend to underestimate the productivity impact of liberalization (a similar argument is found in Syverson, 2011). In an attempt to explore the importance of this bias for our baseline regressions, we have examined the relation between liberalization and firm-level price-cost margins in our sample. ${ }^{19}$ We find no systematic relation between them, which is in line with existing evidence regarding the absence of the impact of European networks liberalization on prices and their dispersion (see Fiorio and Florio, 2009 and the review therein). ${ }^{20}$ Overall, this evidence suggests that there is no systematic bias coming from mark-up and price dynamics. Therefore, mark-up and price dynamics could only introduce pure noise in our TFPR measures, and our estimates could be, if anything, downward biased.

As a further way to check the robustness of our results to using alternative productivity measures, we also report results for labor productivity measured by the logarithm of value added per employee $(\ln (\mathrm{Va} / \mathrm{Empl}))$. Table A3 shows the correlations between different measures of productivity in our sample. The

\footnotetext{
19 We approximate price-cost margins by the earnings before interest, taxes, depreciation and amortization divided by sales, following Aghion et al. (2005). The regressions of price-cost margins on IOL are available upon request.

${ }^{20}$ A number of European Commission evaluations are available at:

http://ec.europa.eu/economy_finance/structural_reforms/product/network_industries/index_en.htm.
} 
correlations are reasonably high, even though the ones between TFPR OLS and other productivity measures are lower.

\subsection{Within-firm productivity change of incumbents}

To explore the within-firm productivity gains from the network services liberalization, we investigate the relationship between the firm-level productivity growth and liberalization in the firm's industry. We account for time-invariant unobserved heterogeneity at the country/industry level, by means of controlling for country and industry fixed effects.

The fixed-effects and first-differences models can often lead to an attenuation bias. This is particularly the case in settings where the exogenous variable of interest is highly auto-correlated and where outcomes are expected to respond to changes in conditions over a longer period of time. This is because, even when the exogenous variable of interest is precisely measured, its variation over short time periods may only poorly approximate the incentives of firms to adjust their productivity. Thus, first differencing eliminates most of the useful information about true incentives to adjust and results in inconsistent estimates (see McKinnish, 2008). This is a potential issue in our setting since we estimate the productivity response of firms to changes in regulatory policy that is highly correlated in time. In our sample, the autocorrelation of the liberalization index is $0.73 .^{21} \mathrm{We}$ therefore follow the literature and use instead a long-differences estimator that tackles this source of bias.

Formally, our baseline regression model can be stated as:

$$
\Delta p_{\text {fcit }}=\beta \Delta L i b_{\text {cit }}+X_{\text {cit }}+\varepsilon_{\text {fict }},
$$

where $\Delta$ denotes the long-difference operator, which corresponds to four-year differences in our baseline specification; ${ }^{22} f$ cit is the index of observation for firm $f$

\footnotetext{
${ }^{21}$ Calculated by regressing the liberalization index on firm fixed effects and applying the Baltagi and $\mathrm{Wu}$ (1999) procedure for testing for the autocorrelation of residuals in unbalanced panel data.

${ }^{22}$ The exact choice of the number of years is subject to a trade-off between the attenuation bias resulting from using a too-short period and a reduction in sample size resulting from a too-long period. We obtain similar results when using 3- or 5-year differences.
} 
in country $c$, industry $i$ and year $t ; p_{f c i t}$ is a firm-level productivity measure and $\mathrm{Lib}_{\text {cit }}$ is the index of liberalization in country-industry-year, IOL or IEL. Finally, the vector $X_{\text {cit }}$ denotes a set of country/industry/year controls. ${ }^{23}$

In order to control for country-specific aggregate trends and shocks, such as the catch-up process of the new member states or the different timing of countryspecific reforms and financial conditions, $X_{c i t}$ includes the full set of country-year fixed effects $\lambda_{c t}$. Furthermore, including $\lambda_{c t}$ mitigates worries that our estimates are affected by the spillovers from other reforms that are simultaneous to the network services liberalization of a given industry, which would be a concern if countries were implementing reforms in the form of reform packages.

Vector $X_{\text {cit }}$ contains the full set of industry fixed effects $\lambda_{i}$ capturing differences in industry-specific average trends. If the liberalization efforts were correlated with unobserved industry-specific global growth opportunities in the crosssection, our estimate of $\beta$ would be biased upwards. Thus, in the model with included country-year and industry fixed effects, the coefficient of interest is identified from the different timing and magnitude of the liberalization across countries within same industry.

In an alternative specification, we control for unobserved differences in country-industry specific trends by replacing industry fixed effects $\lambda_{i}$ with the full set of country-industry fixed effects $\lambda_{c i}$. The country-industry fixed effects absorb all differences in the average trend of productivity at the country-industry level. Therefore, their inclusion considerably reduces the variation that can be used for the identification of $\beta$. Notably, if the pace of the liberalization were constant over the whole sample period in any given country-industry cluster, the coefficient $\beta$ would not be identified.

Finally, we extend the specification by including industry-year fixed effects $\lambda_{i t}$. Controlling for $\lambda_{i t}$ mitigates concerns that the timing and scope of the liberalization by local authorities might be affected by industry-wide global productivity shocks (common across all countries).

\footnotetext{
${ }^{23}$ The set of included controls $X_{\text {cit }}$ correspond to already differenced variables.
} 
Taken together, in our preferred specification, we control for country-industry fixed effects $\lambda_{c i}$, country-year shocks $\lambda_{c t}$ and industry-year shocks $\lambda_{i t}$. Thus, given the use of the four-year differences estimator, $\beta$ is identified only from differences in the dynamics of productivity change in periods of significant liberalization and periods of low liberalization, while controlling for country-specific and industryspecific shocks.

\subsection{Reallocation of market share between incumbents}

To explore the reallocation channel, we investigate the differences in the employment growth of firms in the same industry that differ in their lagged productivity. ${ }^{24}$ As discussed in Section 2, the theory predicts that liberalization that strengthens competition causes inefficient firms to shrink and allows the more efficient firms to increase in size relative to the average firm in the industry.

To test this prediction, we estimate the four-year-differences model of employment growth of the form:

$$
\Delta e m p l_{f c i t}=\alpha \Delta L i b_{c i t}+\beta \Delta L i b_{c i t} \times p_{\text {fict }-4}+\gamma p_{f i c t-4}+X_{c i t}+\varepsilon_{f i c t},
$$

where $\Delta e m p l_{f c i t}$ stands for the change in employment between year $t$ and year $t-4$. If the liberalization has a positive effect on aggregate productivity through the reallocation channel, we would expect coefficient $\beta$ to be positive, indicating that the employment of productive firms is increasing disproportionally more than the employment of relatively less productive firms.

As in the case of specification (1), $X_{\text {cit }}$ includes country-year, industry-year and country-industry fixed effects in order to control for country and industry shocks and country-industry average trends. The sources of identification are same as in case of specification (1).

\footnotetext{
${ }^{24}$ We focus on reallocation in terms of variable inputs, as output/revenues shares would become vaguely defined in increasingly integrated European markets. In this way we also make our results directly comparable with earlier studies regarding the reallocation impact of increased competition (e.g., Bartelsman et al., 2009). Besides, employment growth features among the key policy objectives of the European Union and is pervasively used to evaluate the success of its Internal Market reforms.
} 


\section{Results}

\subsection{Main results}

We present our main estimation results concerning the impact of liberalization on within-firm TFP productivity and cross-firm allocation of resources.

Table 4 presents the results on the impact of liberalization on the four-year average TFP change at the firm level. Panel A presents the results of regressions for the four-year change in IOL and Panel B presents analogous results for the four-year change in IEL. As discussed in detail in Section 3.1, the former is expected to capture more features of the state of market competition that incumbents face. The dependent variable in columns (1)-(4) of both panels is our baseline LP-based estimate of TFPR. Columns (5)-(7) report the estimates using, respectively, the TFPR W-LP, the TFPR OLS, and real value added per employee (see Section 4.2 for details).

The within-firm specification in column (1) of Panel A regresses the average firm TFP-growth on the change of the liberalization index while using country-year fixed effects that capture country-level macro shocks. This points to a $6.3 \%$ increase in within-firm productivity due to a one-unit change in IOL. The regression in column (2) adds industry fixed-effects to control for potential bias driven by a positive correlation between industry-specific trend growth and liberalization. Indeed, the estimate reduces in magnitude and is estimated more precisely. Column (3) controls for country-industry trends instead of industry ones. In this case, the coefficient of interest is identified by the cross-country time variation in the liberalization of a given industry and firm productivity outcomes. This corrects for any positive bias from the differential long-term growth opportunities of the same industry across countries, due to, for example, differences in countries' industrial structure. Consistent with this intuition, the estimate reduces further in column (3).

In column (4), we add industry-year fixed effects that control for any policy and/or technology related shocks that are common across firms operating in the same industry. As a result, the coefficient of interest now increases to $6.4 \%$, suggesting a negative bias in the estimates of columns (1)-(3) that only partially correct for industry-specific time-varying factors. The suggested negative correlation between our liberalization measure and industry-year fixed effects could be due to the fact that policy makers are more willing to carry out liberalization measures when the industry is hit by negative technological shocks. It may also capture increased foreign 
competition driven by overall European-wide liberalization. As a means of robustness checking, columns (5) through (7) repeat the regression of column (4) for our alternative measures of productivity.

Turning to Panel B of Table 4, the estimates overall confirm the presence of within-firm TFP gains from entry liberalization. In contrast to the results in Panel A for changes in IOL, the estimates are uniformly lower (on the order of $2.4 \%$ for a unitchange of the index; see column (4)) and broadly weaker in significance. The differences in estimates between the two panels across the same specifications are due to the difference in the source and degree of variation between IOL and IEL. As discussed in Section 3.1, this difference is arguably driven by different information that these indexes include and the fact that IEL captures one particular aspect of competition that affects incumbent firms only indirectly.

The evidence of strong within-firm TFP gains in Table 4 raises the question whether the initially high-TFP firms also expanded in size in response to the liberalization. As discussed in Section 2, the theory predicts that liberalization should improve productivity by improving the allocation of resources across firms in the industry. This would show up as a stronger correlation between size and productivity across firms in the industry. However, the results we present in Table 5, across all specifications in columns (1)-(7), entail no compelling evidence that such a positive reallocation was underway. ${ }^{25}$

To summarize, the results support the presence of within-firm four-year productivity gains from the liberalization that are on average $5.5 \%$. Assuming that our linear specification is a valid description of all potential liberalization events, our results suggest that a change in IOL score from 0 to 6 , e.g., full liberalization in four years, would be associated with $33 \%$ within-firm productivity gains. To get more intuition about the quantitative importance of our estimates, we examine the

\footnotetext{
${ }^{25}$ We have also investigated the cross-sectional relationship between allocative efficiency and the liberalization index. Using the cross-sectional decomposition of Olley and Pakes (1996), the industry productivity at any point in time can be decomposed into two terms: 1) the simple average of firm-level productivity and 2) the covariance between market shares and productivity. The latter term is a simple proxy for allocative efficiency. Using our sample, we calculated the average OP covariance term for every country/industry and regressed it on the liberalization index while controlling for industry and country fixed effects. The results show no systematic relationship between IOL and the OP covariance term. These regressions are available upon request.
} 
percentage of total actual within-firm productivity change that is explained by the liberalization in our data. To this end, we treat each firm in our sample as part of an "aggregate network services industry", which is defined by all the firms in our sample. We predict the four-year within-firm productivity change based on our estimated coefficient of interest and the change in IOL in the respective countryindustry where a firm operates. Then, we take a weighted average of the predicted within-firm productivity change, where each firm is weighted by its initial employment share out of total employment in our sample. The predicted within-firm productivity growth amounts to $5.2 \%$ on average over our sample period. In a similar way, we find that the weighted average of the actual realized within-firm productivity growth in our sample is on average $13.5 \%$. Therefore, up to $38 \%$ of the within-firm productivity gains of European network services in our sample can be explained by liberalization. This calculation underscores that the EU-wide liberalization efforts can be important drivers of aggregate productivity outcomes.

\subsection{Endogeneity of the liberalization}

In this section, we address the concern that the European network services liberalization policies are not exogenous to productivity shocks of firms operating in the liberalized industries. This concern is relevant because the actual implementation of the reforms adopted at the EU-level is left to national governments. In our empirical framework, by taking long-differences over the liberalization index and controlling for country-industry fixed effects, as well as for country- and industryyear fixed effects, we account for the role of any politico-economic factors with such sources of variation.

Therefore, we are left to correct for any remaining factors varying at the country-industry-year level that are related to local policy choices that determine the degree and timing of liberalization. As an example, national governments may prefer to minimize the political costs of liberalization and choose to liberalize more and/or earlier the industries with weaker expected growth prospects. In this case, due to the negative selection of industries into the liberalization, we would underestimate the effect of liberalization on firm-level TFP. Furthermore, the liberalization policy could be driven by time-varying local industry factors relevant for firm-level productivity, 
such as monopoly power or strong labor unions that relate to the political costs/benefits from liberalization. To the extent that our baseline specification does not explicitly control for such factors, the resulting omitted-variables problem may bias our coefficient of interest.

For these reasons, we investigate whether the observed changes in IOL are correlated with initial industrial characteristics that relate to the political costs/benefits of the liberalization. ${ }^{26}$ The characteristics we consider are the number of firms and the median firm size. These act as a proxy for monopoly power and industry concentration and thereby the scope for the existence of a strong business lobby. Total industry sales proxy for the importance of the industry in the economy. Total employment and the average wage in the industry proxy for the magnitude of political costs that arise from labor unions opposing competition due to the fear of job or wage losses. Finally, the average productivity of the industry proxies for the growth prospects, for example, due to catch-up. ${ }^{27}$

The results are presented in Table 6. In each cell of Panel A, we report the estimated coefficient from the regression of the average four-year change of the liberalization index (IOL) on the industry characteristic in the respective column. The value of industry characteristics is taken as of the beginning of the sample period. In all cases, we control for country and industry fixed effects. In a similar way, in Panel $\mathrm{B}$, we check the correlation between the four-year change in the liberalization index and the four-years-lagged value of each industry characteristic, while controlling for country-year and industry fixed effects. Overall, the results show no statistically significant correlation between the initial industrial characteristics and the subsequent change in IOL. The only exception is the initial total number of firms in the industry that is negatively correlated with subsequent change in IOL in the cross section (at the $10 \%$ significance level). Still, this correlation disappears in the respective panel regression as shown in Panel B.

\footnotetext{
${ }^{26}$ A similar approach is followed by Topalova and Khandelwal (2011).

${ }^{27}$ The total number of firms and total employment are taken from Eurostat. The median firm size (employment) and average wage are calculated using the Amadeus sample.
} 
Finally, in the last column, we investigate the correlation of the change in IOL with its initial level. The latter is the politico-economic outcome that is inherited from the past and summarizes the initial condition of regulation in the industry. We find that it is the only a statistically significant and economically important determinant of the change in IOL. The relationship is even stronger in the panel data estimation, where the estimated t-statistic is close to 10 . The negative correlation between the change in IOL and its initial level captures the fact that, for those industry-country pairs that started as more liberalized (high level of IOL), there was a smaller scope for liberalization and thereby they could experience a smaller change in their IOL index than the change experienced by country-industry pairs in our sample on average.

The correlation between the change in the liberalization index and its lagged value is consistent with the harmonization objective of the EU Directives. To further support this insight, we investigate how the strength of this correlation over earlier periods, 1978-1987 and 1988-1997, compares to the one over our sample period, 1998-2007. For each of the three periods, Panel A of Table 7 presents estimates from regressions of the four-year change in IOL on the four-year lagged IOL and an intercept. The comparison of the estimated constant terms across the three time periods suggests that the 1998-2007 period was the one with the strongest liberalization efforts as the IOL of a fully regulated industry was expected to increase on average by 1.5 over the four years. The IOL of a fully regulated industry has increased only by about 0.7 during the 1988-1997 period, and essentially remained constant during the 1978-1987 period. Furthermore, the 1998-2007 period experienced the highest convergence of IOL, as the estimated coefficient on the lagged IOL in column (1) is negative and highly statistically significant. The convergence pattern is much weaker during the 1988-1997 period, and virtually nonexistent in the 1978-1987 period. Panel B of Table 7 repeats the same exercise while controlling for country-year and industry fixed effects. Even in this case, the strength of the convergence in IOL is almost twice as large in the 1998-2007 period than it is in the 1988-1997 period, while there is no evidence of convergence during the 19881997 period.

The strong harmonization pattern in IOL during 1998-2007 suggests that the initial IOL level serves as a good proxy for the EU command for the network 
industries' liberalization that is exogenous to local firms' TFP growth. Therefore, we can use the lagged level of IOL as an instrument for the change in IOL in each country-industry in our sample over time. By doing so, we seek to explain TFP growth by the change in the liberalization as predicted by the initial liberalization state, given the need to reach common policy objectives as set by the EU-wide harmonization efforts. The identifying assumption is that the initial liberalization state affects firm-level TFP growth only through its effect on the scope for liberalization policy and is uncorrelated with unobserved productivity shocks or other latent factors affecting firm-level productivity.

The results from the two-step efficient GMM estimation, using the four-yearlagged IOL as an instrument, are presented in Panel A of Table 8, while Panel B of the table presents the results from the corresponding first-stage regressions. ${ }^{28}$ The regressions in columns (1)-(3) of Table 8 follow, one by one, our baseline specifications in columns (4)-(6) of Table 4. The GMM estimates are uniformly higher by about one percentage point for all employed measures of TFPR compared to the OLS ones, suggesting a negative bias in the OLS estimates. Such a negative bias arises if local authorities are choosing the timing and the scope of liberalization in order to respond to the prospects of declining industry productivity. For instance, such declining productivity could take place in the face of increasing foreign competition, if the rest of the EU members completed liberalization earlier. Hence, if anything, our evidence suggests a negative selection of industries into liberalization.

\subsection{Additional results}

As discussed in Section 2, there are theoretical reasons to examine whether the positive impact of liberalization is different across firms of different productivity level or size.

To investigate the possibility of the heterogeneous impact of liberalization on firms of different productivities, we split firm-year observations into two categories based on their position relative to the median of the productivity distribution.

\footnotetext{
${ }^{28}$ Any differences between the results between Panel B of Table 10 and column 8 of Table 8 are due to the unbalanced nature of our final firm-level sample.
} 
Specifically, we construct an indicator variable that takes value 1 if the productivity of a given firm is higher than the median productivity of its industry and is 0 otherwise. Then, we extend specification (1) by including the interaction of the lagged value of this dummy variable with the change in the liberalization index.

The resulting specification is

$$
\Delta p_{f c i t}=\beta \Delta L i b_{c i t}+\beta_{h} \Delta L i b_{c i t} * p_{f c i t-4}^{H i g h}+\gamma p_{f c i t-4}^{H i g h}+X_{c i t}+\varepsilon_{f i c t},
$$

where $p_{f c i t-4}^{H i g h}$ is an indicator variable equal to 1 if a firm's productivity is above the median productivity of its industry as of four years ago and is zero otherwise. If productivity gains from liberalization come mostly from the productivity improvements of firms with initially low productivity, we expect $\beta$ to be positive and $\beta_{h}$ to be negative. Including $p_{\text {fcit-4 }}^{\text {High }}$ controls for the possibility of different productivity trajectories of firms that differ in their lagged productivity, i.e., due to 'catch-up' effects. As in the case of specification (1), we include a set of country/industry/year control variables $X_{\text {cit }}$, which consists of country-year fixed effects $\lambda_{c t}$, industry-year fixed effects $\lambda_{i t}$ and country-industry fixed effects $\lambda_{c i}$.

Table 9 presents the estimates of specification (3). The results suggest that the TFP gains from the liberalization are decreasing in the initial productivity of firms. This is in line with the predictions of Schmidt (1997) that when initial competition is very low, then increased competition would decrease managerial slackness, which translates into higher productivity. It is also consistent with the fact that, at the beginning of the liberalization process, the network services industries largely featured state monopolies where managerial slackness concerns are likely to be important (e.g., due to the lack of threat of firing).

The other scope for the heterogeneity of the estimated effect we consider asks whether the liberalization asymmetrically affected firms of different initial size. This is investigated by estimating a model analogous to specification (3), where we replace indicator $p_{\text {fcit-4 }}^{\mathrm{High}}$ by its analog for the firm's position relative to the median of the employment distribution, empl $\mathrm{fcit}_{\text {figh }}^{\mathrm{igh}}$ 


$$
\begin{gathered}
\Delta p_{f c i t}=\beta \Delta L i b_{c i t}+\beta_{h} \Delta L i b_{c i t} * e m p l_{f c i t-4}^{H i g h}+\gamma e m p l_{f c i t-4}^{H i g h}+X_{c i t} \\
+\varepsilon_{f i c t} .
\end{gathered}
$$

The estimates of specification (4) presented in Table 10 do not provide support that the impact of liberalization is heterogeneous across size. This suggests that either the policies were in no way specific to firm size, or that other firm-size-specific distortions did not affect firms' responses in productivity.

\section{Robustness checks}

We perform a series of robustness checks for our main results on the impact of liberalization on within-firm productivity growth and reallocation. First, in Panel A of Table A4, we show that our results are robust to dropping the countries that joined the European Union in 2004, the Czech Republic, Hungary and Poland. If EU accession had a positive impact on the productivity of network services industries due to reasons other than the liberalization of these industries itself, including these countries could bias our results. We thus exclude these three countries from the sample and reestimate our main specifications that correspond to columns (4)-(6) in Table 4 and columns (4)-(6) in Table 5. For the reallocation equation, we report only the coefficient on the interaction term of the change in IOL and lagged productivity. The results are qualitatively similar to our main results.

Second, we investigate whether the countries that are the most represented in our sample drive our results. As Table 1 shows, the most represented countries are Germany, Italy and Spain, each of which accounts for more than $10 \%$ of the sample. In Panels B to D of Table A4, we remove each of these countries one by one and reestimate our main specifications on the resulting subsamples. Again, our results remain qualitatively unchanged.

Third, we investigate whether our results are sensitive to the differences in sample coverage across industries, or to the inclusion of industries with very strong liberalization experiences. We repeat a similar exercise as before by checking the robustness of our results on the subsamples that are created by dropping, one by one, 
each of the suspect industries. Tables A5.a and A5.b show that our results survive also this check.

Fourth, we investigate whether our results are robust to excluding country/industry clusters that have unbalanced firm size distribution relative to the one reported for the aggregate population of firms in Eurostat. In principle, combining several updates of Amadeus should result in a sample that covers most companies in Europe. However, due to differences in reporting requirements among the underlying vendors of $\mathrm{BvD}$, the final sample can be under-sampled in some size categories in some countries/industries. ${ }^{29}$ To do so, we follow a procedure used in Klapper et al. (2006). We use data from Eurostat Structural Business Statistics (SBS) on the true number of firms within country and industry and three size categories defined by employment: 20-49, 50-249 and 250 or more employees. For each country/industry/size category, we calculate the average number of firms between 2004 and 2007 in both Eurostat and our Amadeus sample, and then calculate the ratio $\mathrm{R}_{c i}$ Size of the Eurostat over the Amadeus number of firms to obtain a measure of the under-representation of our sample. ${ }^{30} \mathrm{~A}$ high value of this ratio suggests that the number of firms in our sample is very low compared to the true number reported in SBS. Next, we compare the ratios between the biggest and smallest size categories in a given country/industry cluster. A large difference between the coverage of large and small firms would suggest that the firm size distribution is skewed relative to the population firm-size distribution. To investigate whether this has a significant effect on our results, we drop the industry/country clusters where the relative underrepresentation of small firms to the underrepresentation of large firms (i.e., the ratio of $\mathrm{R}_{c i}$ Low to $\mathrm{R}_{\mathrm{ci}}$ High) is higher than 5 or lower than 0.2. Table A6 shows that our main results are unaffected.

Fifth, Table A7 shows the estimates obtained using 3-year and 5-year differences specifications. As expected, the estimates for the 3-year differences model

\footnotetext{
${ }^{29}$ For example, small German firms are not legally required to disclose (Desai et al., 2003).

${ }^{30}$ The Eurostat SBS data on the firm size distribution have the best coverage after 2004. Additionally, given our version of Amadeus takes care of the survivorship bias, it is reasonable to expect that any sample unbalancedness will be the most pronounced in the cross-section, rather than over time.
} 
are smaller in magnitude, while the estimates for the 5-year differences model are larger than those obtained using the baseline four-years differences specification.

Finally, Table A8 documents that our main results are robust to excluding observations with the imputed values of employment.

\section{Conclusions}

We examined the productivity impact of European-level network services liberalization. To do so, we built an empirical framework that isolates the source of variation in industry-specific liberalization that is exempt of variation in country/industry-specific politico-economic conditions and productivity prospects. Our findings show that, as a response to removing regulatory barriers to entry and reducing state ownership, network services firms experienced on average $5.5 \%$ productivity gains over a four-year period. In our sample, the within-firm average productivity gains due to liberalization account for more than one-third of the actual within-firm average productivity gains of all firms operating in network services industries.

The magnitude of our estimates of within-firm productivity gains is in line with earlier findings in the literature that examines the impact of trade liberalization on the productivity of firms operating in liberalized markets. In particular, since our study concerns eliminating regulatory barriers in output markets, our estimates can be compared to estimates of output tariff reduction in manufacturing. As an illustration, Amiti and Konings (2007) or Topalova and Khandelwal (2011), among others, suggest corresponding estimates on the order of $9.5 \%$ and $3.5 \%$, respectively. To our advantage, since network services are mostly non-tradable, import competition has a limited scope to bias our results.

The distinction between the liberalization of output vs. input markets is an important one, because existing findings in the literature show that a reduction of input tariffs has a significantly stronger productivity impact on firms compared to a reduction of output tariffs. With this distinction in mind, our results are also consistent with Arnold et al. (2008), who find that one unit change in the OECD index of product market regulation implies within-firm productivity gains on the order of $10 \%$. 
They study input liberalization, which suggests why their estimate is larger than ours. Also, they are interested to measure the impact of liberalization in all services, both network and non-network ones, on the productivity of firms operating in any business activity. Our contribution is that we track down the initial source of these gains by focusing on network services that are the most important among all services inputs and the ones that are, to a large extent, liberalized by now.

Finally, we note that our finding that the gains from the liberalization came from the within-firm productivity improvements rather than the reallocation of resources across firms is also in line with earlier studies of liberalization. In this regard, our conclusions regarding reallocation come with a caveat: we lack a full empirical model of entry and exit. Moreover, due to the length of our sample period, our results capture more short-term developments following the liberalization as opposed to long-term effects.

Turning to the policy implications, our findings suggest that the regulatory reforms for network services were successful in increasing the threat of competition for incumbents and thus inducing them to become more productive. Our results are in support of the European Commission's demand to extend liberalization to other market services. 


\section{References}

Acemoglu, D., Aghion, P., and F. Zillibotti (2006) Distance to Frontier, Selection and Economic Growth, Journal of European Economic Association, 4(1), 37-74.

Ackerberg, D.A., Caves, K., and G. Frazer (2006) Structural Identification of Production Functions. Manuscript.

Aghion, P., and P. Howitt (1998) Endogenous Growth Theory, Cambridge: Mass.: The MIT Press.

Aghion, P., Bloom, N., Blundell, R., Griffith, R., and P. Howitt (2005) Competition and Innovation: An Inverted U Relationship, Quarterly Journal of Economics, 120(2), 701-728.

Alesina A., Ardagna, S., Nicoletti, G., and F. Schiatarelli (2005) Regulation and Investment, Journal of European Economic Association, 3(4), 791-825.

Amiti, M., and J. Konings (2007) Trade Liberalization, Intermediate Inputs, and Productivity: Evidence from Indonesia, American Economic Review, 97(5), 16111638.

Ark, B. v., O'Mahoney, M., and M. P. Timmer (2008) The Productivity Gap between Europe and the United States: Trends and Causes, Journal of Economic Perspectives, $22,25-44$.

Arnold, J., Nicoletti, G., and S. Scarpetta (2008) Regulation, Allocative Efficiency and Productivity in OECD Countries: Industry and Firm-Level Evidence, OECD Economics Department Working Paper (4109).

Baltagi, B., and P. Wu (1999) Unequally spaced panel data regressions with AR(1) disturbances. Econometric Theory, 15, 814-823.

Banerjee, A., and E. Duflo (2005) Growth Theory Through the Lens of Development Economics, in Aghion, P., and S. Durlauf, eds., Handbook of Economic Growth, Vol. 1 (Elsevier), 473-552.

Barone, G., and F. Cingano (2011) Service Regulation and Growth: Evidence from OECD Countries, Economic Journal, 121, 931-957.

Bartelsman, E. J., Haltiwanger, J. C., and S. Scarpetta (2009) Cross-Country Differences in Productivity: The Role of Allocation and Selection, NBER Working Papers (15490).

Basu, S., Fernald, J. G., Oulton, N., and S. Srinivasan (2003) The Case of the Missing Productivity Growth: Or, Does Information Technology Explain why Productivity Accelerated in the US but not the UK? NBER Working Papers (10010). 
Beck, T., Demirguc-Kunt, A., and V. Maksimovic (2005) Financial and legal constraints to firm growth: Does firm size matter? Journal of Finance, 60, 137-177.

Bloom, N., Romer, P., and J. Van Reenen (2010) A Trapped Factor Model of Innovation, LSE/Stanford manuscript.

Bloom, N., Draca, M., and J. Van Reenen (2011) Trade Induced Technical Change? The Impact of Chinese Imports on Innovation, IT and Productivity, NBER Working Papers (16717).

Bloom, N., and J. Van Reenen (2007) Measuring and Explaining Management Practices Across Firms and Countries, Quarterly Journal of Economics, 122(4), 13511408.

Bosworth, B. P., and J. E. Tripplett (2002) Baumol's Disease Has Been Cured: IT and Multifactor Productivity in U.S. Services Industries, Brookings Institution manuscript.

Boylaud, O., and G. Nicoletti (2001) Regulation, Market Structure and Performance in Telecommunications, OECD Economics Department Working Papers (237).

Branstetter, L.G., Lima, F., Taylor, L. J., and A. Venâncio (2010) Do Entry Regulations Deter Entrepreneurship and Job Creation? Evidence from Recent Reforms in Portugal, NBER Working Papers (14935).

Conway, P., and G. Nicoletti (2006) Product Market Regulation in the NonManufacturing Sectors of OECD Countries: Measurement and Highlights, OECD Economics Department Working Papers (530).

De Loecker, J. (2011) Product Differentiation, Multiproduct Firms and Estimating the Impact of Trade Liberalization on Productivity, Econometrica, 79(5), 1407-1451

Desai, M., Gompers, P., and J. Lerner (2003) Institutions, Capital Constraints and Entrepreneurial Firm Dynamics: Evidence from Europe, NBER Working Papers (10165).

Eberhardt, M., and C. Helmers (2010) Untested Assumptions and Data Slicing: A Critical Review of Firm-Level Production Function Estimators, University of Oxford, Department of Economics, Economics Series Working Papers (513).

Eslava, M., Haltiwanger, J. C., Kugler, A. D., and M. Kugler (2009) Trade Reforms and Market Selection: Evidence from Manufacturing Plants in Colombia, NBER Working Papers (14935).

Fiorio, C., and M. Florio (2009) The reform of network industries, privatisation and consumers welfare: evidence from the EU15, UNIMI - Research Papers in Economics, Business, and Statistics, Economics Working Papers (31). 
Klette, T. J., and Z. Griliches (1996) The Inconsistency of Common Scale Estimators When Output Prices Are Unobserved and Endogenous, Journal of Applied Econometrics, 11(4), 343-61.

Guner, N., Ventura, G., and Y. Xu. (2008) Macroeconomic Implications of SizeDependent Policies, Review of Economic Dynamics, 11(4), 721-44.

Hsieh, C-T., and P. J. Klenow (2009) Misallocation and Manufacturing TFP in China and India, Quarterly Journal of Economics, 124, 1403-1448.

Inklaar, R., O'Mahony M., and M. P. Timmer (2005) ICT and Europe's Productivity Performance: Industry-Level Growth Account Comparisons with the United States, Review of Income and Wealth, Vol. 51(4), 505-536.

Inklaar, R., Timmer, M. P., and B. van Ark (2008) Market Services Productivity across Europe and the US, Economic Policy, 23, 139-194.

Jamasb T., and M. Pollitt (2005) Electricity Market Reform in the European Union: Review of Progress toward Liberalization \& Integration, The Energy Journal, 26, 1141.

Jorgenson, D. W., Ho, M. S., and K. J. Stiroh (2005) Growth of U.S. Industries and Investments in Information Technology and Higher Education, in Measuring Capital in the New Economy (403-478), National Bureau of Economic Research, Inc.

Klapper, L., Laeven, L., and R. Rajan (2006) Entry regulation as a barrier to entrepreneurship, Journal of Financial Economics, 82(3), 591-629.

Levinsohn, J., and A. Petrin (2003) Estimating Production Functions Using Inputs to Control for Unobservables, The Review of Economic Studies, 70(2), 317-341.

Lucas, R. E. (1978) On the Size Distribution of Business Firms, Bell Journal of Economics, 9, 508-523.

McKinnish, T. (2008) Panel data models and transitory fluctuations in the explanatory variable, Advances in Econometrics, 21, 335-358.

Melitz, M. J. (2003) The Impact of Trade on Intra-Industry Reallocations and Aggregate Industry Productivity, Econometrica, 71, 1695-1725.

Melitz, M. J., and G. Ottaviano (2008) Market size, Trade and Productivity, Review of Economic Studies, 75(1), 295-316.

Nickell, S. J. (1996) Competition and Corporate Performance, Journal of Political Economy, 104(4), 724-46.

Nicoletti, G., and F. L. Pryor (2006) Subjective and Objective Measures of the Extent of Government Regulations, Journal of Economic Behavior and Organization, 59(3), 433-449. 
Nicoletti, G., and S. Scarpetta (2003) Regulation, Productivity and Growth: OECD Evidence, Economic Policy, 36, 9-72.

Olley, G., and A. Pakes (1996) The dynamics of productivity in the telecommunications equipment industry, Econometrica, 64, 1263-1297.

Oulton, N., and S. Srinivasan (2005) Productivity Growth and the Role of ICT in the United Kingdom: An Industry View, 1970-2000, Bank of England Working Papers (259).

Parente, S.L., and E.C. Prescott (1994) Barriers to Technology Adoption and Development, Journal of Political Economy, 102(2), 298-321.

Restuccia, D., and R. Rogerson (2008) Policy Distortions and Aggregate Productivity with Heterogeneous Plants, Review of Economic Dynamics, 11(4), 707-720.

Sapir, A., Aghion, P., Bertola, G., Hellwig, M., Pisani-Ferry, J., Rosati, D., Viñals, J., and H. Wallace (2004) An Agenda for a Growing Europe: The Sapir Report, Oxford University Press.

Schmidt, K. M. (1997) Managerial Incentives and Product Market Competition, Review of Economic Studies, 64(2), 191-213.

Syverson, C. (2011) What Determines Productivity? Journal of Economic Literature, 49(2), 326-365.

Ten Raa, T., and E. N. Wolff (2001) Outsourcing of Services and the Productivity Recovery in the United States Manufacturing in the 1980s and 1990s. Journal of Productivity Analysis, 16, 149-165.

Topalova, P., and A. Khandelwal (2011) Trade Liberalization and Firm Productivity: The Case of India, The Review of Economics and Statistics, 93(3), 995-1009.

Vickers, J. (1995) Concepts of Competition, Oxford Economic Papers, 47(1), 1-23.

Wooldridge, J. M. (2009) On estimating firm-level production functions using proxy variables to control for unobservables, Economics Letters, 104(3), 112-114. 
Tables and Figures

Figure 1.a: Liberalization in Services Industries - 1998 - 2007

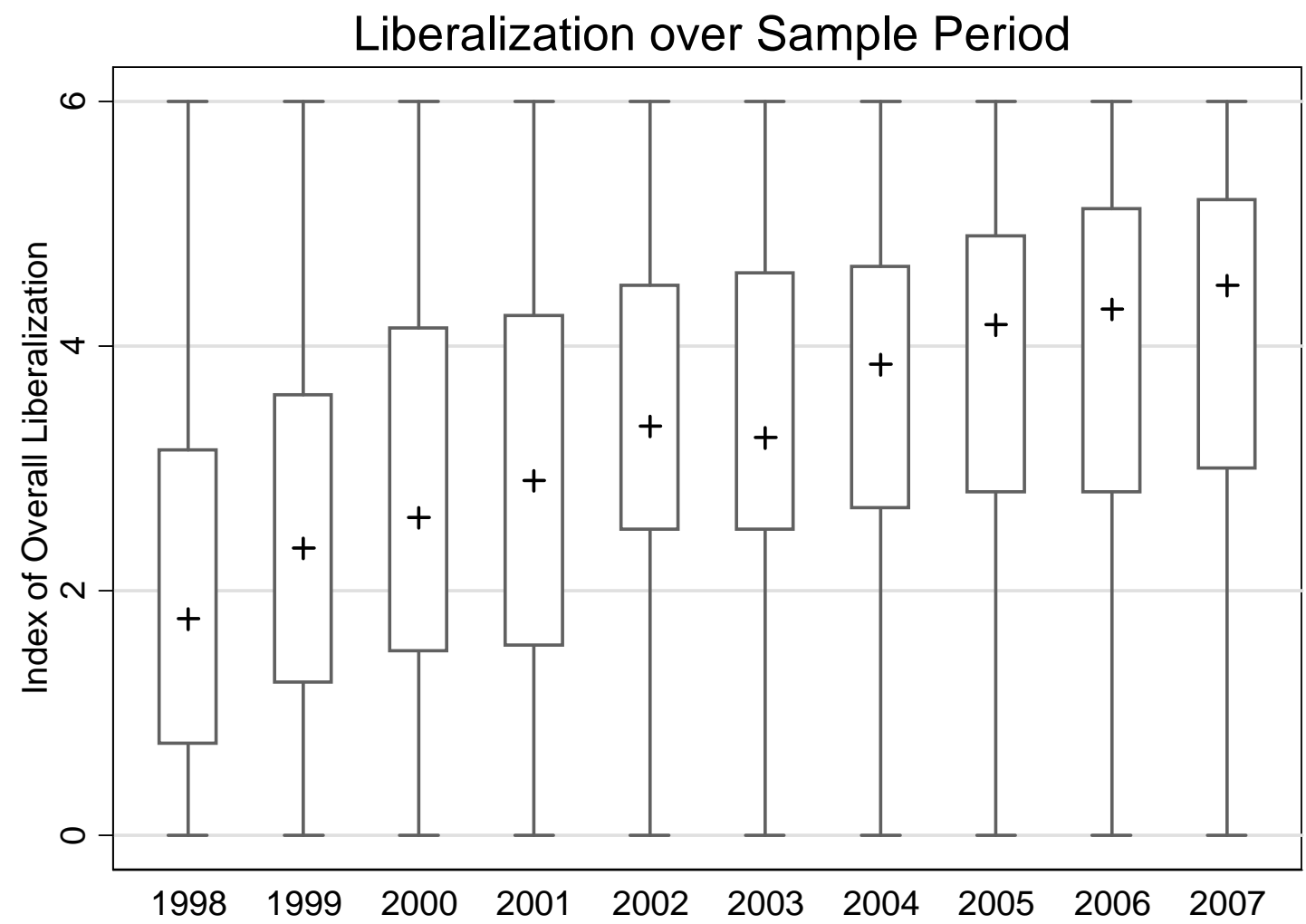

Note: Box-plot of the distribution of the Index of Overall Liberalization over all countries and industries in the sample. Scale is $0-6$ from the most to least restrictive of competition.

Source: OECD indicators of regulation in network industries, Conway and Nicoletti (2006). 
Figure 1.b: Liberalization in Services Industries - 1998 - 2007
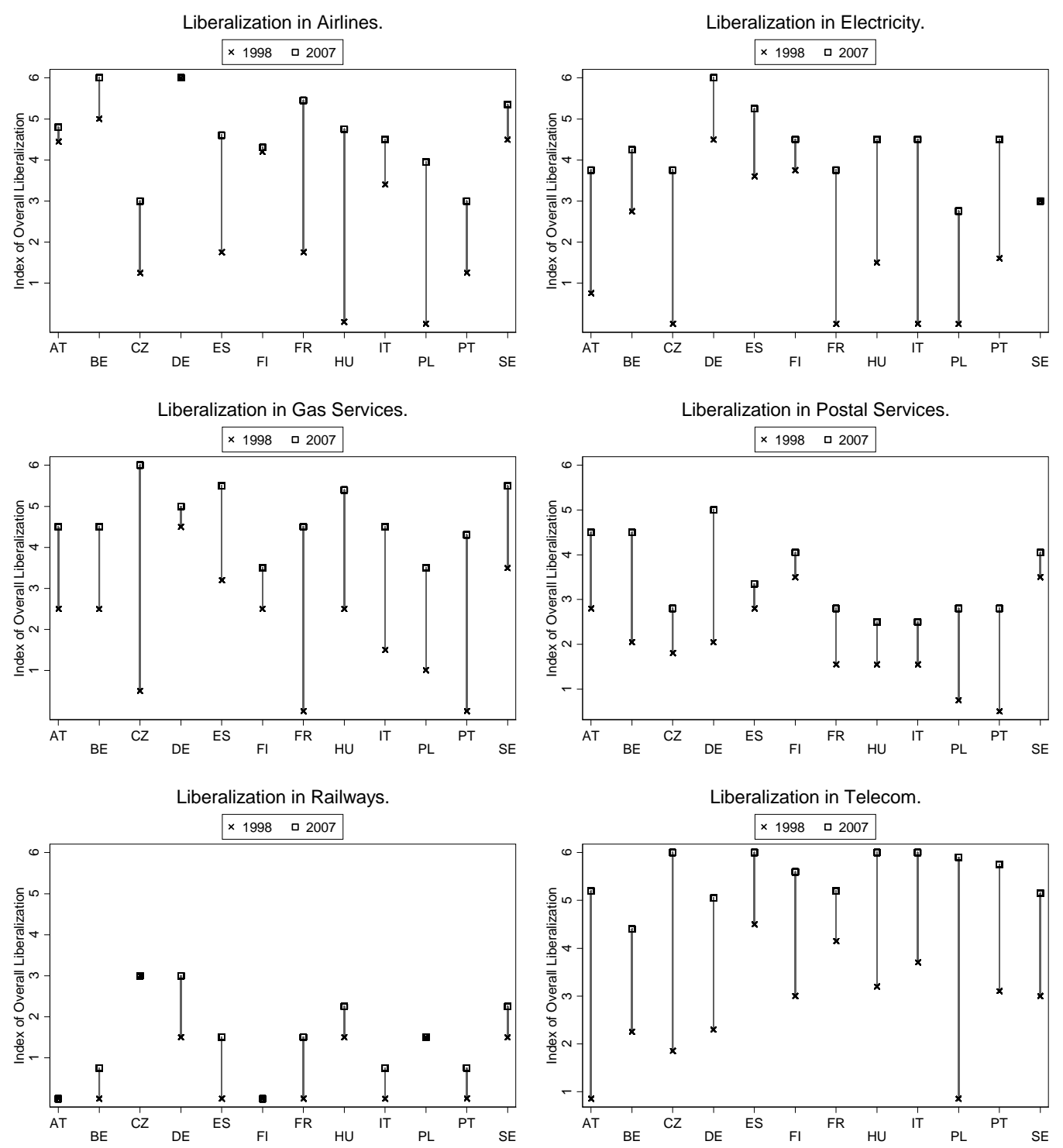

Note: Changes in the Index of Overall Liberalization (IOL). Scale is 0-6 from the most to least restrictive of competition.

Source: OECD indicators of regulation in network industries, Conway and Nicoletti (2006). 
Table 1

Summary Statistics of Services Industries by Country

\begin{tabular}{|c|c|c|c|c|c|c|c|c|c|}
\hline \multirow[b]{2}{*}{ Country } & \multirow[b]{2}{*}{ \# Obs. } & \multicolumn{3}{|c|}{ (1) } & \multicolumn{3}{|c|}{ (2) } & \multicolumn{2}{|c|}{ (3) } \\
\hline & & Pctile 10 & Median & Pctile 90 & Pctile 10 & Median & Pctile 90 & 1998 & 2007 \\
\hline Austria (AT) & 226 & 70.2 & 194.3 & 597.7 & 38 & 470 & 2396 & 1.6 & 4.0 \\
\hline Belgium(BE) & 646 & 67.4 & 207.8 & 796.3 & 26 & 124 & 1159 & 2.9 & 4.4 \\
\hline Czech Rep. (CZ) & 501 & 12.1 & 49.0 & 202.3 & 33 & 150 & 1250 & 1.2 & 4.4 \\
\hline Germany (DE) & 5070 & 91.6 & 197.2 & 416.3 & 30 & 98 & 972 & 4.3 & 5.6 \\
\hline Spain (ES) & 4293 & 16.4 & 50.6 & 346.5 & 22 & 44 & 426 & 3.4 & 4.8 \\
\hline Finland (FI) & 1537 & 29.1 & 127.2 & 347.7 & 25 & 64 & 374 & 3.4 & 4.7 \\
\hline France (FR) & 1523 & 64.0 & 207.8 & 712.7 & 23 & 58 & 669 & 1.5 & 4.7 \\
\hline Hungary (HU) & 802 & 3.8 & 12.6 & 49.4 & 24 & 157 & 1908 & 2.2 & 4.9 \\
\hline Italy (IT) & 3227 & 44.5 & 120.8 & 483.7 & 24 & 56 & 549 & 1.6 & 4.4 \\
\hline Poland (PL) & 1653 & 8.4 & 24.2 & 86.7 & 30 & 135 & 1694 & 0.3 & 3.9 \\
\hline Portugal (PT) & 223 & 30.9 & 110.3 & 603.9 & 23 & 188 & 8649 & 1.6 & 4.3 \\
\hline Sweden (SE) & 1461 & 68.7 & 159.5 & 552.0 & 23 & 44 & 361 & 3.2 & 3.5 \\
\hline Total Sample & 21162 & 19.1 & 126.5 & 415.4 & 24 & 71 & 836 & 2.7 & 4.8 \\
\hline
\end{tabular}

The table reports summary statistics for labor productivity (in 1995 EUR ths.) and employment for twelve countries in our sample. Labor productivity is calculated as the double-deflated value added over employment, where country/sector specific output and intermediate inputs deflators come from EU KLEMS. \# Obs. corresponds to number of observations in Amadeus. Column 3 reports the average value of the Index of Overall Liberalization (IOL) in the first and last year of our sample for each country.

Table 2

Change in the Index of Overall Liberalization over Sample Period

\begin{tabular}{lllllll}
\hline \hline Country & Airlines & Electricity & Gas & Post & Railways & Telecom \\
\hline AT & 0.4 & 3.0 & 2.0 & 1.7 & 0.0 & 1.5 \\
BE & 1.0 & 1.5 & 2.0 & 2.5 & 0.8 & 2.2 \\
CZ & 1.8 & 3.8 & 5.5 & 1.0 & 0.0 & 4.2 \\
DE & 0.0 & 1.5 & 0.5 & 3.0 & 1.5 & 2.8 \\
ES & 2.9 & 1.7 & 2.3 & 0.6 & 1.5 & 1.5 \\
FI & 0.1 & 0.8 & 1.0 & 0.6 & 0.0 & 2.6 \\
FR & 3.7 & 3.8 & 4.5 & 1.3 & 1.5 & 1.1 \\
HU & 4.7 & 3.0 & 2.9 & 0.9 & 0.8 & 2.8 \\
IT & 1.1 & 4.5 & 3.0 & 0.9 & 0.8 & 2.3 \\
PL & 4.0 & 2.8 & 2.5 & 2.1 & 0.0 & 5.1 \\
PT & 1.8 & 2.9 & 4.3 & 2.3 & 0.8 & 2.7 \\
SE & 0.8 & 0.0 & 2.0 & 0.6 & 0.8 & 1.7 \\
Mean & 1.8 & 2.4 & 2.7 & 1.4 & 0.7 & 2.5 \\
\hline
\end{tabular}

The table reports overall change in IOL between the first and last year of our sample for each Country/Industry cluster. 
Table 3

Summary Statistics of Services Industries

(1)

VA / Employee
(2)

Employment

\begin{tabular}{|c|c|c|c|c|c|c|c|}
\hline Country & \# Obs. & Pctile 10 & Median & Pctile 90 & Pctile 10 & Median & Pctile 90 \\
\hline Airlines & 1350 & 53.3 & 152.7 & 325.9 & 26 & 122 & 1705 \\
\hline Electricity & 8188 & 25.5 & 169.3 & 438.8 & 26 & 87 & 1140 \\
\hline Gas Services & 2595 & 43.2 & 165.9 & 615.9 & 24 & 67 & 484 \\
\hline Postal Services & 2664 & 10.5 & 36.4 & 206.5 & 22 & 46 & 430 \\
\hline Railways & 1024 & 15.7 & 55.0 & 166.4 & 27 & 115 & 1815 \\
\hline Telecom & 5341 & 19.5 & 90.3 & 449.0 & 23 & 60 & 650 \\
\hline
\end{tabular}

The table reports summary statistics for labor productivity (in 1995 EUR ths.) and employment for six industries in our sample. \# Obs. corresponds to the number of observations in Amadeus.

Table 4

Liberalization and Within-firm Productivity Change

\begin{tabular}{|c|c|c|c|c|c|c|c|}
\hline & (1) & $(2)$ & $(3)$ & (4) & $(5)$ & $(6)$ & (7) \\
\hline \multirow[t]{4}{*}{ Dependent Variable } & $\triangle \mathrm{TFPR}$ & $\triangle \mathrm{TFPR}$ & $\triangle \mathrm{TFPR}$ & $\triangle \mathrm{TFPR}$ & $\triangle \mathrm{TFPR}$ & $\triangle \mathrm{TFPR}$ & $\Delta \ln (\mathrm{Va} / \mathrm{Empl})$ \\
\hline & LP & LP & LP & LP & W-LP & OLS & \\
\hline & 4-year diff & 4-year diff & 4-year diff & 4-year diff & 4-year diff & 4-year diff & 4-year diff \\
\hline & \multicolumn{7}{|c|}{ Panel A: Effects of Overall Liberalization } \\
\hline$\Delta \mathrm{IOL}$ & $0.063 * * *$ & $0.056 * * *$ & $0.049 * * *$ & $0.064 * * *$ & $0.056 * * *$ & $0.046^{* * *}$ & $0.035 * *$ \\
\hline 4-year diff & $(0.021)$ & $(0.016)$ & $(0.018)$ & $(0.016)$ & $(0.015)$ & $(0.013)$ & $(0.016)$ \\
\hline Country * Year FE & Yes & Yes & Yes & Yes & Yes & Yes & Yes \\
\hline Industry FE & & Yes & & & & & \\
\hline Country * Industry FE & & & Yes & Yes & Yes & Yes & Yes \\
\hline Industry * Year FE & & & & Yes & Yes & Yes & Yes \\
\hline Adjusted R ${ }^{2}$ & 0.059 & 0.093 & 0.119 & 0.124 & 0.203 & 0.157 & 0.175 \\
\hline Country / Industry clusters & 70 & 70 & 70 & 70 & 70 & 70 & 70 \\
\hline \multirow[t]{2}{*}{ Observations } & 6040 & 6040 & 6040 & 6040 & 6040 & 6040 & 6040 \\
\hline & \multicolumn{7}{|c|}{ Panel B: Effects of Entry Liberalization } \\
\hline$\Delta \mathrm{IEL}$ & 0.018 & $0.028 * * *$ & 0.020 & $0.024^{*}$ & $0.027 * *$ & $0.023 * *$ & 0.014 \\
\hline 4-year diff & $(0.012)$ & $(0.010)$ & $(0.015)$ & $(0.013)$ & $(0.012)$ & $(0.009)$ & $(0.011)$ \\
\hline Country * Year FE & Yes & Yes & Yes & Yes & Yes & Yes & Yes \\
\hline Industry FE & & Yes & & & & & \\
\hline Country * Industry FE & & & Yes & Yes & Yes & Yes & Yes \\
\hline Industry * Year FE & & & & Yes & Yes & Yes & Yes \\
\hline Adjusted $\mathrm{R}^{2}$ & 0.053 & 0.090 & 0.117 & 0.121 & 0.202 & 0.156 & 0.175 \\
\hline Country / Industry clusters & 70 & 70 & 70 & 70 & 70 & 70 & 70 \\
\hline Observations & 6040 & 6040 & 6040 & 6040 & 6040 & 6040 & 6040 \\
\hline
\end{tabular}

The table reports estimates from OLS regressions of 4-year differences in productivity on 4-year differences in the Index of Overall Liberalization (IOL) in Panel A, and on 4-year differences in the Index of Entry Liberalization (IEL) in Panel B. TFPR LP is calculated as a residual from estimating a logarithmic Cobb-Douglas revenue production function using a Levinsohn-Petrin approach. TFPR W-LP is calculated by estimating a logarithmic Cobb-Douglas value added production function using a Wooldridge modification of Levinsohn-Petrin approach with unobserved productivity shocks being approximated by 3rd order polynomials in material costs and capital. TFPR OLS is calculated as a residual from a logarithmic regression model of revenue Cobb-Douglas production function estimated separately for each industry by OLS. All specifications include constant, not reported. Robust standard errors (clustered at the country/industry level) are reported in parentheses. ***, **, * denote significance at the $1 \%, 5 \%$ and $10 \%$ level, respectively. 
Table 5

Liberalization and Change in Employment

\begin{tabular}{|c|c|c|c|c|c|c|c|}
\hline & (1) & (2) & (3) & (4) & (5) & (6) & (7) \\
\hline \multirow[t]{2}{*}{ Dependent Variable } & $\Delta$ Empl & $\Delta$ Empl & $\Delta$ Empl & $\Delta$ Empl & $\Delta$ Empl & $\Delta$ Empl & $\Delta$ Empl \\
\hline & 4-year diff & 4-year diff & 4-year diff & 4-year diff & 4-year diff & 4-year diff & 4-year diff \\
\hline Productivity in the & TFPR & TFPR & TFPR & TFPR & TFPR & TFPR & $\ln (\mathrm{Va} / \mathrm{Empl})$ \\
\hline \multirow[t]{2}{*}{ Interaction Term } & LP & LP & LP & LP & W-LP & OLS & \\
\hline & \multicolumn{7}{|c|}{ Panel A: Effects of Overall Liberalization } \\
\hline$\Delta \mathrm{IOL}$ & $0.034 *$ & $0.033 * *$ & $0.040^{*}$ & 0.002 & 0.006 & 0.013 & $0.066^{*}$ \\
\hline 4-year diff & $(0.018)$ & $(0.016)$ & $(0.021)$ & $(0.022)$ & $(0.021)$ & $(0.022)$ & $(0.038)$ \\
\hline$\Delta \mathrm{IOL}^{*}$ Lagged Productivity & -0.012 & -0.007 & -0.004 & 0.008 & 0.012 & 0.002 & $0.024 *$ \\
\hline 4-year diff $* 4$-year lag & $(0.011)$ & $(0.012)$ & $(0.013)$ & $(0.013)$ & $(0.009)$ & $(0.022)$ & $(0.013)$ \\
\hline Lagged Productivity & $-0.029 * * *$ & 0.005 & 0.003 & -0.005 & $-0.025^{* *}$ & $0.096^{* * *}$ & $0.093^{* * *} *$ \\
\hline 4-year lag & $(0.009)$ & $(0.016)$ & $(0.017)$ & $(0.016)$ & $(0.012)$ & $(0.029)$ & $(0.020)$ \\
\hline Country * Year FE & Yes & Yes & Yes & Yes & Yes & Yes & Yes \\
\hline Industry FE & & Yes & & & & & \\
\hline Country $*$ Industry FE & & & Yes & Yes & Yes & Yes & Yes \\
\hline Industry $*$ Year FE & & & & Yes & Yes & Yes & Yes \\
\hline Adjusted $\mathrm{R}^{2}$ & 0.051 & 0.059 & 0.083 & 0.096 & 0.095 & 0.104 & 0.119 \\
\hline Country / Industry clusters & 70 & 70 & 70 & 70 & 70 & 70 & 70 \\
\hline \multirow[t]{2}{*}{ Observations } & 6040 & 6040 & 6040 & 6040 & 6040 & 6040 & 6040 \\
\hline & \multicolumn{7}{|c|}{ Panel B: Effects of Entry Liberalization } \\
\hline$\triangle \mathrm{IEL}$ & 0.016 & $0.027 * *$ & $0.027^{*}$ & 0.010 & 0.019 & 0.011 & 0.031 \\
\hline 4-year diff & $(0.011)$ & $(0.011)$ & $(0.014)$ & $(0.014)$ & $(0.015)$ & $(0.012)$ & $(0.016)$ \\
\hline$\triangle \mathrm{IEL} *$ Lagged Productivity & -0.008 & -0.008 & -0.009 & -0.004 & -0.010 & -0.006 & 0.009 \\
\hline 4-year diff * 4-year lag & $(0.005)$ & $(0.006)$ & $(0.005)$ & $(0.006)$ & $(0.008)$ & $(0.013)$ & $(0.014)$ \\
\hline Lagged Productivity & $-0.035 * * *$ & -0.004 & -0.006 & -0.012 & 0.010 & $0.103 * * *$ & $0.100 * * *$ \\
\hline 4-year lag & $(0.008)$ & $(0.014)$ & $(0.014)$ & $(0.013)$ & $(0.018)$ & $(0.026)$ & $(0.028)$ \\
\hline Country * Year FE & Yes & Yes & Yes & Yes & Yes & Yes & Yes \\
\hline Industry FE & & Yes & & & & & \\
\hline Country $*$ Industry FE & & & Yes & Yes & Yes & Yes & Yes \\
\hline Industry $*$ Year FE & & & & Yes & Yes & Yes & Yes \\
\hline Adjusted $\mathrm{R}^{2}$ & 0.051 & 0.060 & 0.084 & 0.096 & 0.095 & 0.104 & 0.118 \\
\hline Country / Industry clusters & 70 & 70 & 70 & 70 & 70 & 70 & 70 \\
\hline Observations & 6040 & 6040 & 6040 & 6040 & 6040 & 6040 & 6040 \\
\hline
\end{tabular}

The table reports in Panel A the estimates from OLS regressions of 4-year logarithmic differences of firm employment (Empl) on 4-year differences in the Index of Overall Liberalization (IOL), with its interaction with the 4-year lagged productivity measure as given in the column header. Panel B presents the results for the equivalent specifications concerning the 4-year differences in the Index of Entry Liberalization (IEL). All specifications include a constant, not reported. Robust standard errors (clustered at the country/industry level) are reported in parentheses. $* * *, * *$ and $*$ denote significance at the $1 \%, 5 \%$ and $10 \%$ levels, respectively. 
Table 6

Liberalization and Initial Industrial Characteristic

\begin{tabular}{|c|c|c|c|c|c|c|c|c|c|}
\hline & $\begin{array}{c}(1) \\
\text { Total } \\
\text { \# Firms } \\
\text { in log }\end{array}$ & $\begin{array}{c}\text { (2) } \\
\text { Total } \\
\text { \# Employees } \\
\text { in log }\end{array}$ & $\begin{array}{c}(3) \\
\text { Total } \\
\text { Sales } \\
\text { in log }\end{array}$ & $\begin{array}{c}\text { (4) } \\
\text { Mean } \\
\text { Wage } \\
\text { in log }\end{array}$ & $\begin{array}{c}\text { (5) } \\
\text { Median } \\
\text { Employment } \\
\text { in log }\end{array}$ & $\begin{array}{c}(6) \\
\text { Weighted Mean } \\
\text { TFPR LP }\end{array}$ & $\begin{array}{c}(7) \\
\text { Weighted Mean } \\
\text { TFPR W-LP }\end{array}$ & $\begin{array}{c}(8) \\
\text { Weighted Mean } \\
\text { TFPR OLS }\end{array}$ & IOL \\
\hline & \multicolumn{9}{|c|}{ Panel A: Cross-section } \\
\hline & \multicolumn{9}{|c|}{ Dependent Variable: $\Delta$ IOL (average 4 -year change) } \\
\hline & \multicolumn{9}{|c|}{ Explanatory Variable in Column (as of the first year in the sample) } \\
\hline & $-0.238 *$ & -0.038 & -0.025 & -0.016 & 0.051 & -0.161 & -0.045 & -0.223 & $-0.299 * * *$ \\
\hline & $(0.130)$ & $(0.147)$ & $(0.094)$ & $(0.405)$ & $(0.074)$ & $(0.178)$ & $(0.128)$ & $(0.129)$ & $(0.060)$ \\
\hline Country FE & Yes & Yes & Yes & Yes & Yes & Yes & Yes & Yes & Yes \\
\hline Industry FE & Yes & Yes & Yes & Yes & Yes & Yes & Yes & Yes & Yes \\
\hline Adjusted $\mathrm{R}^{2}$ & 0.577 & 0.690 & 0.644 & 0.587 & 0.592 & 0.596 & 0.589 & 0.599 & 0.720 \\
\hline \multirow[t]{6}{*}{ Observations } & 57 & 52 & 55 & 70 & 70 & 70 & 70 & 70 & 70 \\
\hline & \multicolumn{9}{|c|}{ Panel B: Panel } \\
\hline & \multicolumn{9}{|c|}{ Dependent Variable: $\Delta$ IOL (4-year change) } \\
\hline & \multicolumn{9}{|c|}{ Explanatory Variable in Column (lagged 4 years) } \\
\hline & -0.086 & 0.071 & 0.102 & 0.290 & 0.078 & -0.173 & 0.103 & -0.183 & $-0.483 * * *$ \\
\hline & $(0.083)$ & $(0.112)$ & $(0.163)$ & $(0.207)$ & $(0.056)$ & $(0.136)$ & $(0.091)$ & $(0.144)$ & $(0.056)$ \\
\hline Country * Year FE & Yes & Yes & Yes & Yes & Yes & Yes & Yes & Yes & Yes \\
\hline Industry FE & Yes & Yes & Yes & Yes & Yes & Yes & Yes & Yes & Yes \\
\hline Adjusted $\mathrm{R}^{2}$ & 0.242 & 0.234 & 0.220 & 0.213 & 0.211 & 0.213 & 0.209 & 0.210 & 0.504 \\
\hline Observations & 357 & 324 & 330 & 392 & 392 & 392 & 392 & 392 & 392 \\
\hline
\end{tabular}

Each cell of the table reports estimates from a separate regression on the cross-section of industries (panel A) and the panel of industries (panel B) which comprise our firmlevel sample. Panel A reports estimates of regressions of the time-average 4-year change in the Index of Overall Liberalization (IOL) on the variable in column heading, the value of which is taken as of the beginning of the sample period. Panel B reports estimates of regressions of the actual 4-year change in IOL on the 4-year lagged value of the variable in column heading. Total \# Firms is the number of firms in an industry as reported by Eurostat, Total \# Employees is the number of employees in an industry as reported by Eurostat, Total Sales are the total industry sales as reported by Eurostat, Mean Wage is the industry average wage calculated using Amadeus sample, Median Employment is the industry median employment calculated using Amadeus sample. Weighted mean TFPR LP, TFPR W-LP and TFPR OLS are weighted averages of corresponding $(\log )$ productivities with weights given by the revenues shares within the industry. Robust standard errors (clustered at the country level in panel A and the country/industry level in panel B) are reported in parentheses. $* * * * *$ and $*$ denote significance at the $1 \%, 5 \%$ and $10 \%$ levels, respectively. 
Table 7

Convergence in Liberalization in Europe over Time

\begin{tabular}{|c|c|c|c|}
\hline & (1) & (2) & (3) \\
\hline Sample Period & $1998-2007$ & $1988-1997$ & 1978-1987 \\
\hline \multirow[t]{3}{*}{ Dependent Variable } & $\Delta \mathrm{IOL}$ & $\Delta \mathrm{IOL}$ & $\Delta \mathrm{IOL}$ \\
\hline & 4-year diff & 4-year diff & 4-year diff \\
\hline & \multicolumn{3}{|c|}{ Panel A: Model without Controls } \\
\hline IOL & $-0.228 * * *$ & -0.061 & -0.002 \\
\hline 4-year lag & $(0.048)$ & $(0.065)$ & $(0.003)$ \\
\hline \multirow[t]{2}{*}{ Constant } & $1.514 * * *$ & $0.651 * * *$ & $0.013^{*}$ \\
\hline & $(0.199)$ & $(0.097)$ & $(0.007)$ \\
\hline Adjusted $\mathrm{R}^{2}$ & 0.155 & 0.002 & 0.002 \\
\hline \multirow[t]{2}{*}{ Observations } & 427 & 418 & 426 \\
\hline & \multicolumn{3}{|c|}{ Panel B: Model with Additional Controls } \\
\hline IOL & $-0.458 * * *$ & $-0.236 * * *$ & 0.005 \\
\hline 4-year lag & $(0.051)$ & $(0.081)$ & $(0.007)$ \\
\hline Country $*$ Year FE & Yes & Yes & Yes \\
\hline Industry FE & Yes & Yes & Yes \\
\hline Adjusted $\mathrm{R}^{2}$ & 0.474 & 0.303 & 0.002 \\
\hline Observations & 427 & 418 & 426 \\
\hline
\end{tabular}

The table reports estimates from industry-level OLS regressions of 4-year differences in the Index of Overall Liberalization (IOL) on the 4-year lagged value of IOL. The sample is comprised of 12 countries and 6 network industries that are included in the Amadeus firm-level sample. Regressions are estimated separately over 3 periods: 1978-1987, 1988-1997 and 1998-2007. Panel A presents results for a simple linear model with included intercept. Panel B presents results for the model that includes additional controls: country/year fixed effects and industry fixed effects. Robust standard errors (clustered at the country/industry level) are reported in parentheses. $* * *, * *$ and $*$ denote significance at the $1 \%, 5 \%$ and $10 \%$ levels, respectively.

Table 8

Liberalization and Within-firm Productivity Change: IV Estimates

\begin{tabular}{|c|c|c|c|}
\hline & (1) & $(2)$ & (3) \\
\hline Productivity Measure & $\triangle \mathrm{TFPR}$ & $\triangle \mathrm{TFPR}$ & $\triangle \mathrm{TFPR}$ \\
\hline \multirow[t]{3}{*}{ Estimation Method } & LP & W-LP & OLS \\
\hline & 4-year diff & 4-year diff & 4-year diff \\
\hline & \multicolumn{3}{|c|}{ Panel A: Second-Stage Regression } \\
\hline$\Delta \mathrm{IOL}$ & $0.079 * * *$ & $0.053 * * *$ & $0.052 * * *$ \\
\hline 4-year diff & $(0.017)$ & $(0.017)$ & $(0.015)$ \\
\hline Country $*$ Year FE & Yes & Yes & Yes \\
\hline Country $*$ Industry FE & Yes & Yes & Yes \\
\hline Industry * Year FE & Yes & Yes & Yes \\
\hline Country / Industry clusters & 70 & 70 & 70 \\
\hline \multirow[t]{2}{*}{ Observations } & 6040 & 6040 & 6040 \\
\hline & \multicolumn{3}{|c|}{ Panel B: First-Stage Regression } \\
\hline Lagged IOL & $-1.018 * * *$ & $-1.018 * * *$ & $-1.018 * * *$ \\
\hline 4-year lag & $(0.028)$ & $(0.028)$ & $(0.028)$ \\
\hline Partial $\mathrm{R}^{2}$ & 0.79 & 0.79 & 0.79 \\
\hline F-statistics & 1307.75 & 1307.75 & 1307.75 \\
\hline $\mathrm{p}$-value & 0.000 & 0.000 & 0.000 \\
\hline
\end{tabular}

The table reports estimates of 2-step GMM regressions of 4-year differences in productivity on 4-year differences in the Index of Overall Liberalization (IOL) instrumented by 4-year lagged IOL. All specifications include a constant, not reported. Robust standard errors (clustered at the country/industry level) are reported in parentheses. For the first stage regression, the bottom panel reports the estimated coefficient and the standard error of 4-year lagged IOL, its partial R2, F-statistics of the test of its significance and corresponding p-value. $* * *, * *$ and $*$ denote significance at the $1 \%, 5 \%$ and $10 \%$ levels, respectively. 
Table 9

Efffects of Overall Liberalization on Firms of Different Productivity

\begin{tabular}{|c|c|c|c|}
\hline & $(1)$ & $(2)$ & (3) \\
\hline Productivity Measure & $\triangle \mathrm{TFPR}$ & $\triangle \mathrm{TFPR}$ & $\triangle \mathrm{TFPR}$ \\
\hline \multirow[t]{2}{*}{ Estimation Method } & LP & W-LP & OLS \\
\hline & 4-year diff & 4-year diff & 4-year diff \\
\hline$\Delta \mathrm{IOL}$ & $0.076^{* * *}$ & $0.068 * * *$ & $0.055 * * *$ \\
\hline 4-year diff & $(0.020)$ & $(0.019)$ & $(0.018)$ \\
\hline$\Delta \mathrm{IOL} *$ Lagged High Productivity & -0.034 & -0.037 & -0.029 \\
\hline 4 -year diff $* 4$-year lag & $(0.024)$ & $(0.031)$ & $(0.024)$ \\
\hline Lagged High Productivity & -0.034 & $-0.156 * * *$ & $-0.156 * * *$ \\
\hline 4-year lag & $(0.024)$ & $(0.051)$ & $(0.047)$ \\
\hline Country $*$ Year FE & Yes & Yes & Yes \\
\hline Country * Industry FE & Yes & Yes & Yes \\
\hline Industry * Year FE & Yes & Yes & Yes \\
\hline Adjusted $\mathrm{R}^{2}$ & 0.146 & 0.229 & 0.199 \\
\hline Country / Industry clusters & 70 & 70 & 70 \\
\hline Observations & 6040 & 6040 & 6040 \\
\hline
\end{tabular}

The table reports estimates from OLS regressions of 4-year differences in productivity on 4-year differences in the Index of Overall Liberalization (IOL) interacted with the dummy variable, Lagged High Productivity, which takes value one if the productivity of a given firm was above the median productivity of its respective industry as of 4 years ago and zero otherwise. All specifications include a constant, not reported. Robust standard errors (clustered at the country/industry level) are reported in parentheses. $* * * * *$ and $*$ denote significance at the $1 \%, 5 \%$ and $10 \%$ levels, respectively.

Table 10

Efffects of Overall Liberalization on Firms of Different Size

\begin{tabular}{|c|c|c|c|}
\hline & $\overline{(1)}$ & $\overline{(2)}$ & $\overline{(3)}$ \\
\hline Productivity Measure & $\triangle \mathrm{TFPR}$ & $\Delta \mathrm{TFPR}$ & $\triangle \mathrm{TFPR}$ \\
\hline \multirow[t]{2}{*}{ Estimation Method } & LP & W-LP & OLS \\
\hline & 4-year diff & 4-year diff & 4-year diff \\
\hline$\Delta \mathrm{IOL}$ & $0.066^{* * *}$ & $0.064 * * *$ & $0.052 * * *$ \\
\hline 4-year diff & $(0.021)$ & $(0.016)$ & $(0.018)$ \\
\hline$\Delta \mathrm{IOL} *$ Lagged High Employment & -0.003 & -0.018 & -0.013 \\
\hline 4-year diff $* 4$-year lag & $(0.024)$ & $(0.019)$ & $(0.020)$ \\
\hline Lagged High Employment & -0.003 & -0.001 & $0.036 * *$ \\
\hline 4-year lag & $(0.024)$ & $(0.020)$ & $(0.016)$ \\
\hline Country * Year FE & Yes & Yes & Yes \\
\hline Country * Industry FE & Yes & Yes & Yes \\
\hline Industry * Year FE & Yes & Yes & Yes \\
\hline Adjusted $\mathrm{R}^{2}$ & 0.125 & 0.203 & 0.158 \\
\hline Country / Industry clusters & 70 & 70 & 70 \\
\hline Observations & 6040 & 6040 & 6040 \\
\hline
\end{tabular}

The table reports estimates from OLS regressions of 4-year differences in productivity on 4-year differences in the Index of Overall Liberalization (IOL) interacted with the dummy variable, Lagged High Employment, which takes value one if the employment of a given firm was above the median productivity of its respective industry as of 4 years ago and zero otherwise. All specifications include a constant, not reported. Robust standard errors (clustered at the country/industry level) are reported in parentheses. $* * *, * *$ and $*$ denote significance at the $1 \%, 5 \%$ and $10 \%$ levels, respectively. 


\section{Appendix}

Table A1

The ETCR Indicators: Regulatory Areas by Industry

\begin{tabular}{llllll}
\hline \hline & \multicolumn{5}{c}{ Regulatory areas } \\
\cline { 2 - 6 } & Barriers to entry & $\begin{array}{c}\text { Public } \\
\text { ownership }\end{array}$ & Market structure & $\begin{array}{c}\text { Vertical } \\
\text { integration }\end{array}$ & Price controls \\
\hline Airlines & $\mathrm{X}$ & $\mathrm{X}$ & & \\
Electricity & $\mathrm{X}$ & $\mathrm{X}$ & & $\mathrm{X}$ \\
Gas Services & $\mathrm{X}$ & $\mathrm{X}$ & $\mathrm{X}$ & $\mathrm{X}$ & \\
Postal Services & $\mathrm{X}$ & $\mathrm{X}$ & & \\
Railways & $\mathrm{X}$ & $\mathrm{X}$ & $\mathrm{X}$ & $\mathrm{X}$ \\
Telecom & $\mathrm{X}$ & $\mathrm{X}$ & $\mathrm{X}$ & & \\
\hline
\end{tabular}

The table reports regulatory areas covered by the ETCR for individual industries. " $X$ " denotes a regulatory area that is covered by the respective ETCR as separate index. Source: Table 2 of Conway and Nicoletti (2006).

Table A2

The Correspondence among Industry Classifications

\begin{tabular}{lllll}
\hline \hline & NACE r. 1.1 & $\begin{array}{c}\text { NACE r. 1.1 } \\
\text { 2 digit }\end{array}$ & Eurostat & EU KLEMS \\
\hline Airlines & 621,622 & 62 & I62 & 60 t63 \\
Electricity & 401 & 40 & E401 & E \\
Gas Services & 402 & 40 & E402 & E \\
Postal Services & 641 & 64 & I641 & 64 \\
Railways & 601 & 60 & I601 & 60 t63 \\
Telecom & 642 & 64 & I642 & 64 \\
\hline
\end{tabular}

Table A3

Correlations of Firm-level Productivity Measures

\begin{tabular}{cccc}
\hline \hline & \multicolumn{4}{c}{ TFPR LP } & TFPR W-LP & TFPR OLS \\
\cline { 2 - 4 } TFPR W-LP & 0.88 & & \\
TFPR OLS & 0.55 & 0.49 & \\
In (VA/Empl) & 0.64 & 0.75 & 0.62 \\
\hline
\end{tabular}


Table A4

Robustness to Removing Countries

\begin{tabular}{|c|c|c|c|c|c|c|}
\hline & (1) & (2) & (3) & (4) & (5) & (6) \\
\hline \multirow[t]{3}{*}{ Dependent Variable } & $\Delta \mathrm{TFPR}$ & $\triangle \mathrm{TFPR}$ & $\triangle \mathrm{TFPR}$ & $\Delta$ Empl & $\Delta$ Empl & $\Delta$ Empl \\
\hline & LP & W-LP & OLS & & & \\
\hline & 4-year diff & 4-year diff & 4-year diff & 4-year diff & 4-year diff & 4-year diff \\
\hline \multirow{3}{*}{$\begin{array}{l}\text { Productivity in the } \\
\text { Interaction Term }\end{array}$} & & & & TFPR & TFPR & TFPR \\
\hline & & & & LP & W-LP & OLS \\
\hline & \multicolumn{6}{|c|}{ Panel A: Removing Czech Republic, Hungary and Poland } \\
\hline$\Delta \mathrm{IOL}$ & $0.077 * * *$ & $0.067 * * *$ & $0.056 * * *$ & & & \\
\hline 4-year diff & $(0.019)$ & $(0.015)$ & $(0.017)$ & & & \\
\hline$\Delta \mathrm{IOL} *$ Productivity & & & & 0.003 & 0.006 & -0.008 \\
\hline 4-year diff $* 4$-year lag & & & & $(0.016)$ & $(0.011)$ & $(0.029)$ \\
\hline \multirow[t]{2}{*}{ Observations } & 5371 & 5371 & 5371 & 5371 & 5371 & 5371 \\
\hline & \multicolumn{6}{|c|}{ Panel B: Removing Germany } \\
\hline$\Delta \mathrm{IOL}$ & $0.044 * * *$ & $0.052 * * *$ & $0.034 * *$ & & & \\
\hline 4-year diff & $(0.017)$ & $(0.017)$ & $(0.014)$ & & & \\
\hline$\Delta \mathrm{IOL} *$ Productivity & & & & 0.002 & 0.009 & -0.001 \\
\hline 4-year diff $* 4$-year lag & & & & $(0.014)$ & $(0.010)$ & $(0.023)$ \\
\hline \multirow[t]{2}{*}{ Observations } & 4341 & 4341 & 4341 & 4341 & 4341 & 4341 \\
\hline & \multicolumn{6}{|c|}{ Panel C: Removing Italy } \\
\hline$\Delta \mathrm{IOL}$ & $0.060 * * *$ & $0.042 *$ & $0.036^{* *}$ & & & \\
\hline 4-year diff & $(0.021)$ & $(0.022)$ & $(0.016)$ & & & \\
\hline$\Delta \mathrm{IOL} *$ Productivity & & & & 0.009 & 0.011 & 0.013 \\
\hline 4-year diff $* 4$-year lag & & & & $(0.016)$ & $(0.012)$ & $(0.025)$ \\
\hline \multirow[t]{2}{*}{ Observations } & 5267 & 5267 & 5267 & 5267 & 5267 & 5267 \\
\hline & \multicolumn{6}{|c|}{ Panel D: Removing Spain } \\
\hline$\Delta \mathrm{IOL}$ & $0.064 * * *$ & $0.052 * * *$ & $0.047 * * *$ & & & \\
\hline 4-year diff & $(0.018)$ & $(0.018)$ & $(0.015)$ & & & \\
\hline$\Delta \mathrm{IOL} *$ Productivity & & & & 0.008 & 0.013 & 0.000 \\
\hline 4-year diff $* 4$-year lag & & & & $(0.014)$ & $(0.010)$ & $(0.021)$ \\
\hline Observations & 4887 & 4887 & 4887 & 4887 & 4887 & 4887 \\
\hline
\end{tabular}

The table reports estimates from OLS regressions for specifications corresponding to columns (4-6) of the table 4 and columns (4-6) of the table 5. For each panel, all specifications are estimated on a subsample obtained by removing corresponding set of countries. For productivity regressions, we report estimate of the coefficient on the (4-year) change in the IOL. For employment regressions, we report estimate of the coefficient on the (4-year) change in the IOL interacted with a (4-year) lagged productivity measure specified in column header. Robust standard errors (clustered at the country/industry level) are reported in parentheses. $* * *, * *$ and $*$ denote significance at the $1 \%, 5 \%$ and $10 \%$ levels, 
Table A5.a

Robustness to Removing Industries

\begin{tabular}{|c|c|c|c|c|c|c|}
\hline & (1) & (2) & (3) & (4) & (5) & (6) \\
\hline \multirow[t]{3}{*}{ Dependent Variable } & $\triangle \mathrm{TFPR}$ & $\Delta \mathrm{TFPR}$ & $\Delta \mathrm{TFPR}$ & $\Delta \mathrm{Empl}$ & $\Delta \mathrm{Empl}$ & $\Delta$ Empl \\
\hline & LP & W-LP & OLS & & & \\
\hline & 4-year diff & 4-year diff & 4-year diff & 4-year diff & 4-year diff & 4-year diff \\
\hline Productivity in the & & & & TFPR & TFPR & TFPR \\
\hline \multirow[t]{2}{*}{ Interaction Term } & & & & LP & W-LP & OLS \\
\hline & \multicolumn{6}{|c|}{ Removing Airlines } \\
\hline$\Delta \mathrm{IOL}$ & $0.067 * * *$ & $0.054 * * *$ & $0.048 * * *$ & & & \\
\hline 4-year diff & $(0.018)$ & $(0.015)$ & $(0.014)$ & & & \\
\hline$\Delta \mathrm{IOL} *$ Productivity & & & & 0.003 & 0.010 & 0.007 \\
\hline 4 -year diff $* 4$-year lag & & & & $(0.014)$ & $(0.010)$ & $(0.021)$ \\
\hline \multirow[t]{2}{*}{ Observations } & & & -0.006 & & & 0 \\
\hline & \multicolumn{6}{|c|}{ Removing Electricity } \\
\hline$\Delta \mathrm{IOL}$ & $0.063 * * *$ & $0.067 * * *$ & $0.049 * * *$ & & & \\
\hline 4-year diff & $(0.016)$ & $(0.015)$ & $(0.014)$ & & & \\
\hline$\Delta \mathrm{IOL} *$ Productivity & & & & 0.018 & 0.018 & 0.008 \\
\hline 4 -year diff $* 4$-year lag & & & & $(0.019)$ & $(0.011)$ & $(0.028)$ \\
\hline \multirow[t]{2}{*}{ Observations } & 3290 & 3290 & 3290 & 3290 & 3290 & 3290 \\
\hline & \multicolumn{6}{|c|}{ Removing Gas } \\
\hline$\Delta \mathrm{IOL}$ & $0.048 * *$ & $0.057 * * *$ & $0.025^{*}$ & & & \\
\hline 4-year diff & $(0.020)$ & $(0.019)$ & $(0.015)$ & & & \\
\hline$\Delta \mathrm{IOL} *$ Productivity & & & & 0.014 & 0.020 & -0.001 \\
\hline 4 -year diff $* 4$-year lag & & & & $(0.015)$ & $(0.012)$ & $(0.026)$ \\
\hline Observations & 5221 & 5221 & 5221 & 5221 & 5221 & 5221 \\
\hline
\end{tabular}

The table reports estimates from OLS regressions for specifications corresponding to columns (4-6) of the table 4 and columns (4-6) of the table 5. For each panel, all specifications are estimated on a subsample obtained by removing corresponding set of industries. For productivity regressions, we report estimate of the coefficient on the (4-year) change in the IOL. For employment regressions, we report estimate of the coefficient on the (4-year) change in the IOL interacted with a (4-year) lagged productivity measure specified in column header. Robust standard errors (clustered at the country/industry level) are reported in parentheses. $* * *, * *$ and $*$ denote significance at the $1 \%, 5 \%$ and $10 \%$ levels, 
Table A5.b

Robustness to Removing Industries

\begin{tabular}{|c|c|c|c|c|c|c|}
\hline & (1) & (2) & (3) & (4) & (5) & (6) \\
\hline \multirow[t]{3}{*}{ Dependent Variable } & $\triangle \mathrm{TFPR}$ & $\triangle \mathrm{TFPR}$ & $\Delta \mathrm{TFPR}$ & $\Delta$ Empl & $\Delta$ Empl & $\Delta$ Empl \\
\hline & LP & W-LP & OLS & & & \\
\hline & 4-year diff & 4-year diff & 4-year diff & 4-year diff & 4-year diff & 4-year diff \\
\hline \multirow{3}{*}{$\begin{array}{l}\text { Productivity in the } \\
\text { Interaction Term }\end{array}$} & & & & TFPR & TFPR & TFPR \\
\hline & & & & LP & W-LP & OLS \\
\hline & \multicolumn{6}{|c|}{ Removing Post } \\
\hline$\Delta \mathrm{IOL}$ & $0.072 * * *$ & $0.058 * * *$ & $0.049 * * *$ & & & \\
\hline 4-year diff & $(0.016)$ & $(0.015)$ & $(0.013)$ & & & \\
\hline$\Delta \mathrm{IOL} *$ Productivity & & & & 0.008 & 0.014 & 0.008 \\
\hline 4 -year diff $* 4$-year lag & & & & $(0.014)$ & $(0.010)$ & $(0.022)$ \\
\hline \multirow[t]{2}{*}{ Observations } & & & -0.014 & & & 0 \\
\hline & \multicolumn{6}{|c|}{ Removing Railways } \\
\hline$\Delta \mathrm{IOL}$ & $0.063 * * *$ & $0.053 * * *$ & $0.043 * * *$ & & & \\
\hline 4-year diff & $(0.016)$ & $(0.015)$ & $(0.013)$ & & & \\
\hline$\Delta \mathrm{IOL} *$ Productivity & & & & 0.007 & 0.012 & 0.003 \\
\hline 4-year diff $* 4$-year lag & & & & $(0.014)$ & $(0.010)$ & $(0.022)$ \\
\hline \multirow[t]{2}{*}{ Observations } & 5826 & 5826 & 5826 & 5826 & 5826 & 5826 \\
\hline & \multicolumn{6}{|c|}{ Removing Telecom } \\
\hline$\Delta \mathrm{IOL}$ & $0.068 * * *$ & $0.040 *$ & $0.059 * * *$ & & & \\
\hline 4-year diff & $(0.019)$ & $(0.020)$ & $(0.017)$ & & & \\
\hline$\Delta \mathrm{IOL} *$ Productivity & & & & -0.002 & -0.002 & -0.025 \\
\hline 4-year diff $* 4$-year lag & & & & $(0.015)$ & $(0.010)$ & $(0.021)$ \\
\hline Observations & 4753 & 4753 & 4753 & 4753 & 4753 & 4753 \\
\hline
\end{tabular}

The table reports estimates from OLS regressions for specifications corresponding to columns (4-6) of the table 4 and columns (4-6) of the table 5. For each panel, all specifications are estimated on a subsample obtained by removing corresponding set of industries. For productivity regressions, we report estimate of the coefficient on the (4-year) change in the IOL. For employment regressions, we report estimate of the coefficient on the (4-year) change in the IOL interacted with a (4-year) lagged productivity measure specified in column header. Robust standard errors (clustered at the country/industry level) are reported in parentheses. $* * *, * *$ and $*$ denote significance at the $1 \%, 5 \%$ and $10 \%$ levels, respectively. 
Table A6

Robustness to Removing Unbalanced Country/Industry Clusters

\begin{tabular}{|c|c|c|c|c|c|c|}
\hline & (1) & (2) & (3) & (4) & (5) & (6) \\
\hline \multirow[t]{3}{*}{ Dependent Variable } & $\Delta \mathrm{TFPR}$ & $\Delta \mathrm{TFPR}$ & $\triangle \mathrm{TFPR}$ & $\Delta \mathrm{Empl}$ & $\Delta \mathrm{Empl}$ & $\Delta \mathrm{Empl}$ \\
\hline & LP & W-LP & OLS & & & \\
\hline & 4-year diff & 4-year diff & 4-year diff & 4-year diff & 4-year diff & 4-year diff \\
\hline Productivity in the & & & & TFPR & TFPR & TFPR \\
\hline Interaction Term & & & & LP & W-LP & OLS \\
\hline$\Delta \mathrm{IOL}$ & $0.066 * * *$ & $0.060 * * *$ & $0.050 * * *$ & & & \\
\hline 4-year diff & $(0.017)$ & $(0.015)$ & $(0.014)$ & & & \\
\hline$\Delta \mathrm{IOL} *$ Productivity & & & & 0.005 & 0.014 & 0.006 \\
\hline 4-year diff $* 4$-year lag & & & & $(0.014)$ & $(0.010)$ & $(0.022)$ \\
\hline Country / Industry clusters & 60 & 60 & 60 & 60 & 60 & 60 \\
\hline Observations & 5688 & 5688 & 5688 & 5688 & 5688 & 5688 \\
\hline
\end{tabular}

The table reports estimates from OLS regressions for specifications corresponding to columns (4-6) of the table 4 and columns (4-6) of the table 5 on the subsample created by removing country/industry clusters for which the firm size distribution appears unbalanced relative to firms size distribution reported in Eurostat. See section 6 for the description of the method used to indentify unbalanced clusters. For productivity regressions, we report estimate of the coefficient on the (4-year) change in the IOL. For employment regressions, we report estimate of the coefficient on the (4-year) change in the IOL interacted with a (4-year) lagged productivity measure specified in column header. Robust standard errors (clustered at the country/industry level) are reported in parentheses. $* * *, * * *$ denote significance at the $1 \%$, $5 \%$ and $10 \%$ level, respectively.

Table A7

Robustness to Different Long Differences Specifications

\begin{tabular}{|c|c|c|c|c|c|c|}
\hline & (1) & $\overline{(2)}$ & (3) & $\overline{(4)}$ & $\overline{(5)}$ & (6) \\
\hline Dependent Variable & $\begin{array}{l}\Delta \mathrm{TFPR} \\
\mathrm{LP}\end{array}$ & $\begin{array}{l}\Delta \text { TFPR } \\
\text { W-LP }\end{array}$ & $\begin{array}{c}\Delta \mathrm{TFPR} \\
\text { OLS }\end{array}$ & $\Delta \mathrm{Empl}$ & $\Delta$ Empl & $\Delta$ Empl \\
\hline Productivity in the & & & & TFPR & TFPR & TFPR \\
\hline \multirow[t]{2}{*}{ Interaction Term } & & & & LP & W-LP & OLS \\
\hline & \multicolumn{6}{|c|}{ Model in 3 year differences } \\
\hline $\begin{array}{l}\Delta \text { IOL } \\
\quad \text { 3-year diff }\end{array}$ & $\begin{array}{l}0.056 * * * \\
(0.018)\end{array}$ & $\begin{array}{l}0.037 * \\
(0.019)\end{array}$ & $\begin{array}{l}0.041 * * * \\
(0.015)\end{array}$ & & & \\
\hline $\begin{array}{l}\Delta \mathrm{IOL} * \text { Productivity } \\
\text { 3-year diff } * 3 \text {-year lag }\end{array}$ & & & & $\begin{array}{l}0.009 \\
(0.013)\end{array}$ & $\begin{array}{l}0.013 \\
(0.009)\end{array}$ & $\begin{array}{l}0.015 \\
(0.021)\end{array}$ \\
\hline \multirow[t]{2}{*}{ Observations } & 8051 & 8051 & 8051 & 8051 & 8051 & 8051 \\
\hline & \multicolumn{6}{|c|}{ Model in 5 year differences } \\
\hline$\Delta \mathrm{IOL}$ & $0.087 * * *$ & $0.062 * *$ & $0.053 * * *$ & & & \\
\hline 5-year diff & $(0.023)$ & $(0.026)$ & $(0.016)$ & & & \\
\hline$\Delta \mathrm{IOL} *$ Productivity & & & & 0.003 & 0.007 & 0.015 \\
\hline 5 -year diff $* 5$-year lag & & & & $(0.016)$ & $(0.013)$ & $(0.031)$ \\
\hline Observations & 4455 & 4455 & 4455 & 4455 & 4455 & 4455 \\
\hline
\end{tabular}

The table reports estimates from OLS regressions for 3-year and 5-year differences specifications corresponding to columns (4-6) of the table 4 and columns (4-6) of the table 5. For productivity regressions, we report estimate of the coefficient on the change in the IOL. For employment regressions, we report estimate of the coefficient on the change in the IOL interacted with a lagged productivity measure specified in column header. Robust standard errors (clustered at the country/industry level) are reported in parentheses. $* * *, * *$ and $*$ denote significance at the $1 \%, 5 \%$ and $10 \%$ levels, respectively. 
Table A8

Robustness to Removing Observations with Imputed Employment

\begin{tabular}{|c|c|c|c|c|c|c|}
\hline & (1) & $(2)$ & (3) & (4) & $(5)$ & (6) \\
\hline \multirow[t]{3}{*}{ Dependent Variable } & $\triangle \mathrm{TFPR}$ & $\triangle \mathrm{TFPR}$ & $\triangle \mathrm{TFPR}$ & $\Delta$ Empl & $\Delta \mathrm{Empl}$ & $\Delta \mathrm{Empl}$ \\
\hline & LP & W-LP & OLS & & & \\
\hline & 4-year diff & 4-year diff & 4-year diff & 4-year diff & 4-year diff & 4-year diff \\
\hline Productivity in the & & & & TFPR & TFPR & TFPR \\
\hline Interaction Term & & & & LP & W-LP & OLS \\
\hline$\Delta \mathrm{IOL}$ & $0.064 * * *$ & $0.051 * * *$ & $0.044 * * *$ & & & \\
\hline 4-year diff & $(0.015)$ & $(0.014)$ & $(0.014)$ & & & \\
\hline$\Delta \mathrm{IOL} *$ Productivity & & & & 0.014 & 0.015 & 0.005 \\
\hline 4-year diff $* 4$-year lag & & & & $(0.014)$ & $(0.010)$ & $(0.021)$ \\
\hline Country / Industry clusters & 60 & 60 & 60 & 60 & 60 & 60 \\
\hline Observations & 5473 & 5473 & 5473 & 5473 & 5473 & 5473 \\
\hline
\end{tabular}

The table reports estimates from OLS regressions for specifications corresponding to columns (4-6) of the table 4 and columns (4-6) of the table 5 on the subsample created by removing observations with imputed value of employment. For productivity regressions, we report estimate of the coefficient on the (4-year) change in the IOL. For employment regressions, we report estimate of the coefficient on the (4-year) change in the IOL interacted with a (4year) lagged productivity measure specified in column header. Robust standard errors (clustered at the country/industry level) are reported in parentheses. $* * *, *$ and $*$ denote significance at the $1 \%, 5 \%$ and $10 \%$ levels, respectively. 


\section{Working Paper Series}

ISSN 1211-3298

Registration No. (Ministry of Culture): E 19443

Individual researchers, as well as the on-line and printed versions of the CERGE-EI Working Papers (including their dissemination) were supported from the following institutional grants:

- Economic Aspects of EU and EMU Entry [Ekonomické aspekty vstupu do Evropské unie a Evropské měnové unie], No. AVOZ70850503, (2005-2011);

Specific research support and/or other grants the researchers/publications benefited from are acknowledged at the beginning of the Paper.

(c) Jan Bena, Peter Ondko, and Evangelia Vourvachaki, 2011

All rights reserved. No part of this publication may be reproduced, stored in a retrieval system or transmitted in any form or by any means, electronic, mechanical or photocopying, recording, or otherwise without the prior permission of the publisher.

Published by

Charles University in Prague, Center for Economic Research and Graduate Education (CERGE) and

Economics Institute ASCR, v. v. i. (EI)

CERGE-El, Politických vězňů 7, 11121 Prague 1, tel.: +420 224005 153, Czech Republic.

Printed by CERGE-EI, Prague

Subscription: CERGE-EI homepage: http://www.cerge-ei.cz

Phone: + 420224005153

Email: office@cerge-ei.cz

Web: http://www.cerge-ei.cz

Editor: Michal Kejak

Editorial board: Jan Kmenta, Randall Filer, Petr Zemčík

The paper is available online at http://www.cerge-ei.cz/publications/working_papers/.

ISBN 978-80-7343-255-3 (Univerzita Karlova. Centrum pro ekonomický výzkum a doktorské studium)

ISBN 978-80-7344-247-7 (Národohospodářský ústav AV ČR, v. v. i.) 
CERGE-EI

P.O.BOX 882

Politických vězňů 7

11121 Praha 1

Czech Republic http://www.cerge-ei.cz 